\title{
KOMUNIKASI LINGKUNGAN PADA GERAKAN BANK SAMPAH SEBAGAI UPAYA PEMBERDAYAAN MASYARAKAT DI TANGERANG SELATAN
}

\author{
Mirza Shahreza \\ NRP: I362170021
}

Komunikasi lingkungan adalah bidang khusus dalam kajian ilmu komunikasi yang secara khusus membahas mengenai lingkungan. Lingkungan terdiri dari lingkungan biotik, abiotik dan juga terkait dengan lingkungan sosial dimana manusia memiliki peran penting dalam ekosistem di bumi. Menurut Alexander Flor, komunikasi lingkungan adalah "penerapan pendekatan komunikasi, prinsip, strategi, dan teknik untuk pengelolaan dan perlindungan lingkungan." (Flor, 2084). Begitu pula definisi yang dinyatakan oleh J. Robert Cox, komunikasi lingkungan adalah "wahana untuk memahami lingkungan dan hubungan kita dengan dunia alam, media simbolis yang digunakan untuk membangun kepedulian lingkungan dan merundingkan tanggapan masyarakat." Komunikasi lingkungan adalah pragmatis dimana "ia memberi tahu, mendidik membujuk kita dan konstitutif, karena secara halus menciptakan makna dan mengarahkan kesadaran ke dunia yang lebih luas. "(Cox, 2010). Jadi dari dua paparan diatas, bisa dikatakan bahwa komunikasi lingkungan adalah suatu upaya untuk melindungi alam dari bentuk degradasi, upaya yang pragmatis agar muncul kesadaran masyarakat dan dunia terkait pentingnya masalah lingkungan dengan pendekatan konteks komunikasi. Komunikasi lingkungan merupakan bentuk dari penyeimbangan dari arus program pembangunan dan moderenisasi yang ada kalanya mengabaikan masalah lingkungan sehingga munculkan kerusakan alam (lingkungan).

Gerakan Bank sampah bisa diasumsikan sebagai gerakan sosial yang menjadi wadah atau media dimana proses komunikasi lingkungan dapat dilakukan. Bank sampah merupakan gabungan gerakan sosial dan gerakan lingkungan. Sampah merupakan isu yang sangat penting bagi peradaban di dunia. Masalah sampah yang sudah menumpuk terutama sampah plastik menjadi masalah global di dunia dan Indoenesia menjadi negara urutan kedua memberikan kontribusi sampah plastik dilautan. ${ }^{1}$ Permasalahannya sampah bisa dikatakan isu yang bisa jadi tidak diperhatikan bahkan cenderung tidak dipedulikan, karena bisa jadi sampah yang

\footnotetext{
${ }^{1}$ Cnnindonesia.com, Indonesia Penyumbang Sampah Plastik Terbesar Kedua Dua, https://www.cnnindonesia.com/gaya-hidup/20160222182308-277-112685/indonesia-penyumbangsampah-plastik-terbesar-ke-dua-dunia,
} 
merupakan sesuatu yang dibuang sehingga lebih mudah untuk dilupakan atau dibiarkan.

\section{Code: Bank Sampah}

Kota Tangerang Selatan memiliki masalah sampah yang serius dengan volume yang semakin banyak terutama dari hasil buangan (limbah) dari rumah tangga. Hal tersebut tergambar dari data-data sekunder yang penulis dapatkan dari beberapa media online dibawah ini.

Persoalan sampah memang masih menjadi persoalan pelik bagi kota-kota di Indonesia. Tak terkecuali bagi Kota Tangerang Selatan sebagai kota yang tengah berkembang pesat (kabartangsel.com, 23 Juli 2013).

Sampah menjadi salah satu permasalahan kota Tangerang Selatan (Tangsel). Tangsel menghasilkan sampah kurang lebih 880 ton setiap hari. Dalam keterangan tertulis dari Dinas Lingkungan Hidup Pemkot Tangsel, Jumat, Kepala Bidang Persampahan dari Dinas Lingkungan Hidup Pemkot Tangsel, Yepi Suherman, berfikir keras untuk menanggulangi sampah. Yepi mencetuskan dan perkenalkan program bank sampah kepada masyarakat

(Detik.com, 19 Mei 2017).

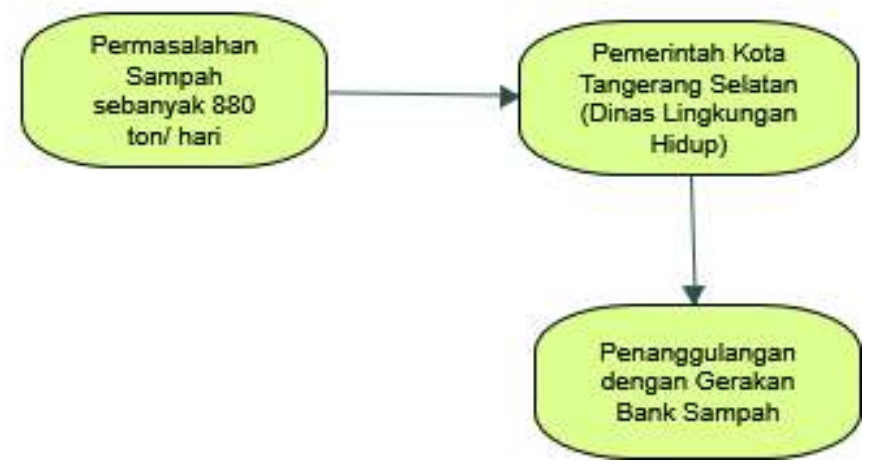

Diagram 1: Penanggulangan Permasalahan Sampah Pemerintah Kota Tangerang Selatan (diolah dengan software Nvivo 12)

Setelah berjalan hampir lima tahun kondisi Bank Sampah sudah relatif berjalan dan sudah terbangun 208 Bank Sampah yang tersebar di 7 Kecamatan. Permasalahan utama juga terkait lahan untuk Tempat Pemprosesan Akhir Sampah yang berlokasi di Cipeucang, Serpong sesuai yang dikutip dibawah ini.

Meski hanya menampung 30 persen sampah Tangerang Selatan setiap harinya, TPA Cipecang kini sudah penuh. Tingginya tumpukan sampah mencapai 12 meter dan telah memenuhi area sanitary landfill seluas 1 hektare tersebut. 
"Meski sudah penuh, kami tetap upayakan sampah yang masuk tetap dikelola di sana," kata Benyamin. Caranya dengan memadatkan dan meratakan tumpukan sampah yang ada (Tempo.co, 23 Agustus 2015).

Volume sampah di Kota Tangerang Selatan (Tangsel) setiap harinya tergolong besar karena mencapai 880 ton. Pemkot Tangsel kian dihadapkan persoalan pelik karena saat ini baru memiliki satu Tempat Pemprosesan Akhir Sampah, yakni di Cipeucang, Serpong (sindonews.com, 2 Juni 2017).

Program Bank Sampah diharapkan dapat mengurangi volume sampah rumah tangga sehingga timbunan sampah di pembuangan akhir dapat diminimalisir. Namun, setelah berjalan selama hampir 5 tahun dari 208 Bank Sampah yang telah terbentuk hanya 50 persen yang aktif seperti kutipan dibawah ini.

Kota Tangerang Selatansat ini mengalami persoalan terkait pengelolaan sampah. Hal itu diungkapkan langsung Kepala Bidang Persampahan Dinas Lingkungan Hidup Tangerang Selatan, Yepi Suherman. Ia menjelaskan, dari 208 bank sampah yang dibentuk, hanya 50 persen yang saat ini masih aktif. Padahal program tersebut sudah digalakkan sedari tahun 2013 silam (tribunnews.com, 21 Agustus 2017).

Dari temuan data diatas jelas ada suatu permasalahan dalam perjalanan program Bank Sampah di Kota Tangerang Selatan, yaitu keaktifan dari Bank Sampah hanya 50 persen dari yang sudah dibentuk. Sehingga hal ini perlu dilakukan sebuah evaluasi agar bisa memperbaiki langkah-langkah yang telah dilakukan.

\section{Code: Komunikator Lingkungan}

Pemerintah kota Tangerang Selatan masih belum mampu menangani permasalahan persampahan karena adanya beberapa kendala yang dihadapi, seperti yang diutarakan sebagai berikut.

Aparat Pemerintah Kota Tangerang Selatan belum mampu menangani masalah sampah secara maksimal selama lima tahun terakhir ini. Masalah sampah masih menjadi momok kota hasil pemekaran Kabupaten Tangerang itu. Bahkan ancaman krisis sampah menghantui kota ini menyusul penuhnya Tempat Pengolahan Akhir Sampah Cipecang satu satunya milik pemerintah daerah itu. "Ternyata tidak gampang menangani sampah perkotaan ini,"ujar Wakil Wali Kota Tangerang Selatan Benyamin Davnie (Tempo.co, 23 Agustus 2015). 
Benyamin mengatakan banyak kendala yang merintangi program penanganan sampah di kota berpenduduk 1,4 juta jiwa tersebut. Dari kesadaran masyarakat yang tidak paham cara mengelola sampah yang baik, sulitnya mendapatkan teknologi pengolahan sampah yang canggih dan tepat hingga terbatasnya lahan TPA Cipecang. "Bu Airin (Wali Kota Airin Rachmi Diany) dan saya telah berupaya, tapi kendala masih menghadang,"kata Benyamin (Tempo.co, 23

Agustus 2015).

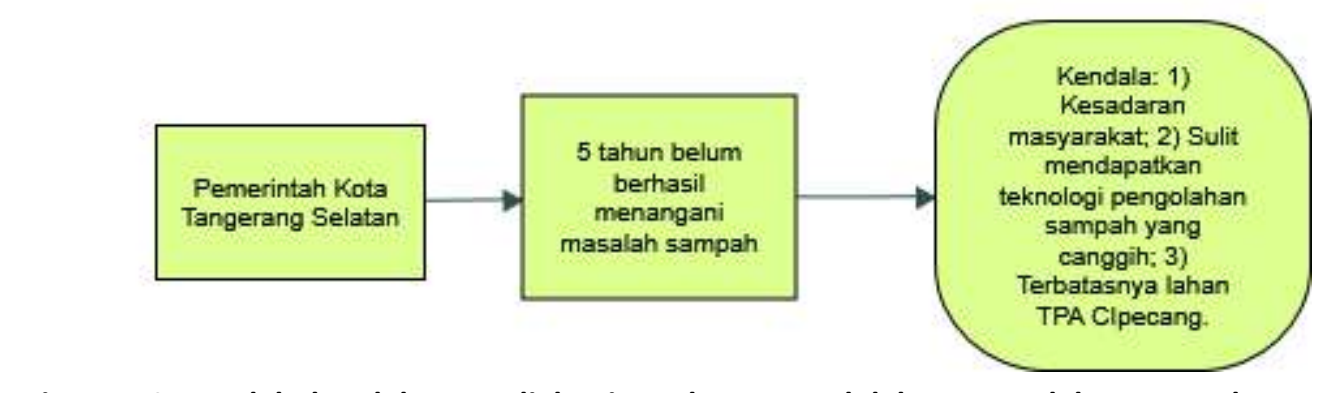

Diagram 2: Kendala-kendala yang dialami Pemkot Tangsel dalam pengolahan sampah (diolah dengan software Nvivo 12)

Benyamin mengungkapkan, produksi sampah di Tangerang Selatan mencapai 800 ton setiap harinya. Sampah tersebut dihasilkan dari 500 ribu kepala keluarga, pasar tradisional dan kawasan pertokoan. Dari sekian banyak sampah tersebut, hanya 30 persen yang terangkut ke TPA Cipecang, 20 persen tereduksi melalui bank sampah, tempat pengolahan sampah $3 \mathrm{R}$ yang kini beroperasi sebanyak 41 titik. Sisanya belum tertangani (Tempo.co, 23 Agustus 2015).

Uniknya, pembangunan bank sampah yang segera diwujudkan di wilayah Kota Tangsel itu diberi nama Airin Airin Rachmi Diany Tangerang Selatan atau disingkat Airaditas (kabartangsel.com, 23 Juli 2013).

Penanganan sampah di kota yang baru berusia muda ini, memang sangat pelik dikarenakan lahan Tempat Penampungan Akhir (TPA) Cipecang yang tidak luas, juga belum mendapatkan solusi berupa teknologi pengolahan sampah yang tepat. Kalau menggunakan mesin pembakar sampah (incinerator), sudah mendapatkan penolakan dari warga karena tidak ramah lingkungan dan berpotensi polusi udara. Untuk melalukan program pengolahan sampah mandiri, yaitu $3 \mathrm{R}$ (Reuse, Ruduce, Recycle) masyarakat belum terbiasa dan juga belum faham. Setelah dikampanyekan dan mulai berjalan ternyata dengan adanya pemilahan dan sudah terlihat dampaknya. 


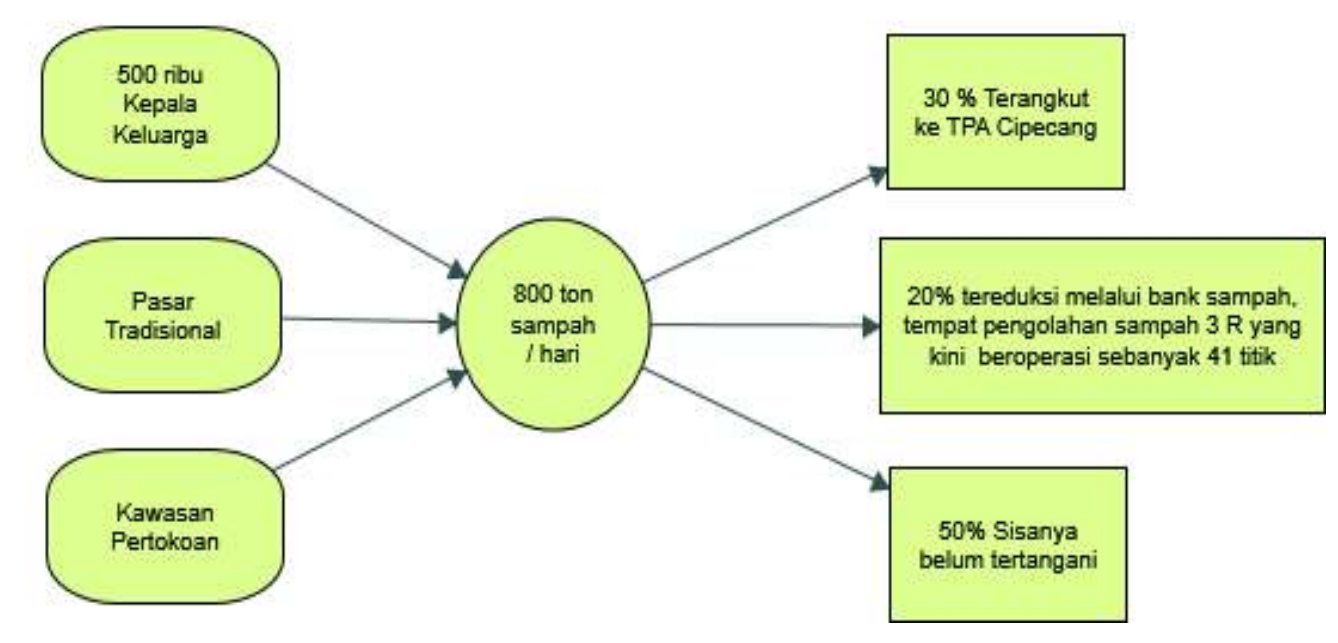

Diagram 3: penguraian sampah harian dari 3 sumber utama sampah

(diolah dengan software Nvivo 12)

Berdasarkan diagram diatas menunjukan bahwa upaya yang telah dilakukan oleh Pemkot Tangerang Selatan terhadap masalah volume sampah yang melebihi kapasitas Tempat Pembuangan Akhir (TPA) Cipecang yang hanya menampung hanya $30 \%$ dari keseluruhan sampah perkotaan, telah terurai atau tereduksi hanya $20 \%$ dari pengolahan sampah, yaitu dari pemilahan sampah yang masih bernilai melalui Bank Sampah dan proses pengolahan $3 \mathrm{R}$, namun masih menjadi PR adalah $50 \%$ yang tidak atau belum tertangani. Sehingga masih perlu upaya yang sungguh-sungguh agar dapat secara signifikan menyelesaikan masalah persampahan. Dengan angka yang cukup besar, yaitu 50\% sampah yang tidak tertangani dapat dibayangkan bagaimana sampah-sampah tersebut akan berceceran diberbagai tempat yang sudah pasti akan merusak lingkungan, keindahan, dapat menimbulkan aroma yang tidak sedap bahkan juga berpotensi menimbulkan bibit penyakit.

\section{Node: LSM}

Saat memulai program bank sampah langkah yang perlu dilakukan oleh Pemerintah Kota Tangerang Selatan adalah melakukan pemetaan sosial agar kampanye program atau sebuah gerakan dapat efektif dan pesan bisa sampai dengan tepat kepada masyarakat umum. Dengan melihat karakteristik masyarakat Tangerang Selatan yang sebenarnya penduduk asli zaman dahulunya adalah hidup Bertani dan sekarang karena pembangunan yang begitu pesat sudah banyak lahan pertanian yang berubah menjadi perumahan. Jadi Tangerang Selatan adalah Kota baru yang masih memiliki kultur pedesaan di beberapa tempat. Ternyata dalam struktur sosial masyarakatnya masih terdapat elemen-elemen yang sangat penting dan 
berpengaruh, yaitu adalah kelompok-kelompok masyarakat beserta tokoh-tokoh yang menjadi panutan (opinion leader). Pada kenyataannya kelompok masyarakat yang mereka memang mempunyai interaksi sosial yang tinggi dan intensif mereka menjadi corong terdepan dalam menangani masalah sampah perkotaan.

Kelompok masyarakat yang tergabung dalam Bank Sampah di Kota Tangerang Selatan (Tangsel) kini telah jadi corong terdepan dalam penanggulangan masalah sampah perkotaan. Organisasi ini diharapkan mampu memberikan edukasi bahwa ternyata sampah memiliki nilai ekonomi dan mau mengajak seluruh elemen masyarakat mengelolanya (tangseloke.com, 10 September 2013).

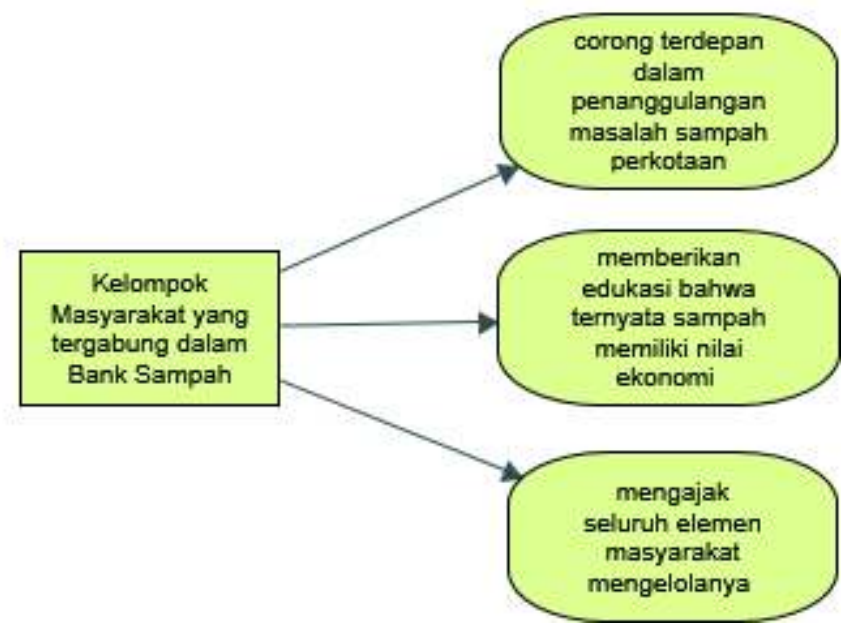

Diagram 4: Peran Kelompok Masyarakat dalam gerakan Bank Sampah (diolah dengan software Nvivo 12)

"Bank sampah dapat berjalan apabila ada terpenting ada Kelompok Swadaya Masyarakat (KSM) yang mau mengurus. Soal tempat sebetulnya tidak terlalu luas," tandasnya (kabartangsel.com, 6 Juni 2014).

Dia bilang, kesadaran tersebut merupakan bentuk tanggungjawab dari kelompok Karang Taruna di Sawah Baru terhadap kebersihan lingkungan sekitarnya. Apalagi, sebaran bank sampah dilingkungan penduduk bisa menekan volume sampah perkotaan. Sebab, sampah yang dihasilkan dari rumah tangga tidak semuanya dibuang ke Tempat 7 Akhir (TPA) Cipeucang, Serpong. "Semoga ini bisa diikuti oleh kelompok masyarakat lainnya. Karena ada sisi ekonomi dalam pengembangan bank sampah yang dikelola warga," tandasnya (bidiktangsel.com, 23 Januari 2018).

Berdasarkan data diatas, terkait dengan gerakan bank sampah yang terpenting adalah adanya kelompok swadaya masyarakat (KSM) yang bersedia berperan aktif 
dan menjadi pengurusnya. Kegiatan ini tidak memerlukan lawan yang luas, cukup memanfaatkan lapangan, halaman, fasilitas sosial, ada beberapa tempat menggunakan sentral titik di masjid atau musholah. Pengangkutan dilakukan adanya sudah setiap hari menampung, ada yang seminggu atau per dua minggu sekali melakukan kegiatan bank sampah, dengan proses pengumpulan, penimbangan, dihitung dan dicatat dibuku tabungan bank sampah, setelah itu di angkat langsung oleh pengepul sampah yang biasanya siang menjelang sore. Jadi sampah tidak berserakan lama, satu hari itu juga langsung bersih kembali.

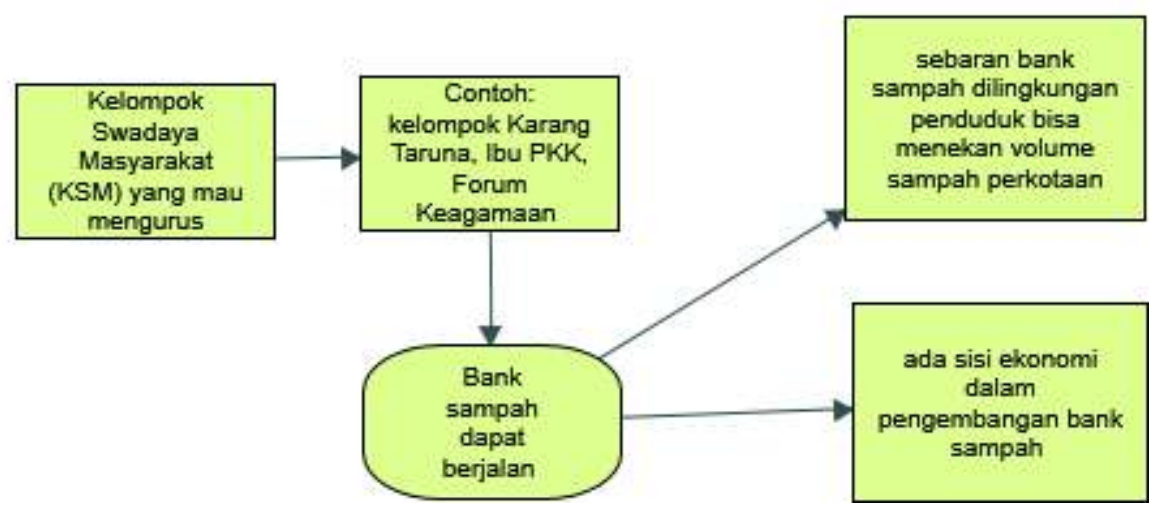

Diagram 4: Gerakan Bank Sampah berjalan karena adanya Kelompok Swadaya Masyarakat (diolah dengan software Nvivo 12)

Dengan bergabung di Forkas, sampah tak sulit dijual karena pembeli langsung datang ke lokasi. Warga pun sangat antusias karena sampah-sampah tak hanya dibuang di bak sampah, tapi bisa bernilai ekonomis. "Program ini selain bisa menciptakan lingkungan bersih juga membuat wargaguyub," ujar Ketua Forum Warga CSJ Surono. Koordinator Bank Sampah Kecamatan Ciputat Dimas Wiwoko mengatakan, kehadiran bank sampah adalah bentuk kearifan lokal. Sebab sejak dini warga memiliki kesadaran dan kepedulian tinggi untuk menciptakan lingkungan yang bersih. Selain mengubah sampah bernilai lebih ekonomis, bank sampah juga menjadi gerakan bersama mewujudkan kota yang bersih. "Ini menjadi pintu sebagai akses untuk menyelaraskan dengan program Pemkot Tangsel mengatasi sampah," ujar Dimas (metro.sindonews.com, 2 Juni 2017).

Setelah beberapa tahun terbentuk bank sampah dan sudah mulai banyak dari data awal pada bulan Agustus 2015 sudah terdapat 41 titik pengolahan sampah yang berbasis bank sampah. Akhirnya terbentuklah Forum Komunikasi Bank Sampah atau yang disingkat Forkas. Dengan adanya Forkas menjadi wadah koordinasi dan konsultasi sesame penggerak bank sampah di kota Tangerang Selatan. Masalah penjualan sampah terkoordinasi dengan baik dengan kerjasama dengan pengepul/ pembeli sampah dan menjadi forum berkumpul, bershilaturahim, serta menciptakan 
suasana 'guyub' yang membuat keharmonisan tercipta dan juga bersama-sama mewujudkan lingkungan dan kota yang bersih, indah, dan nyaman.

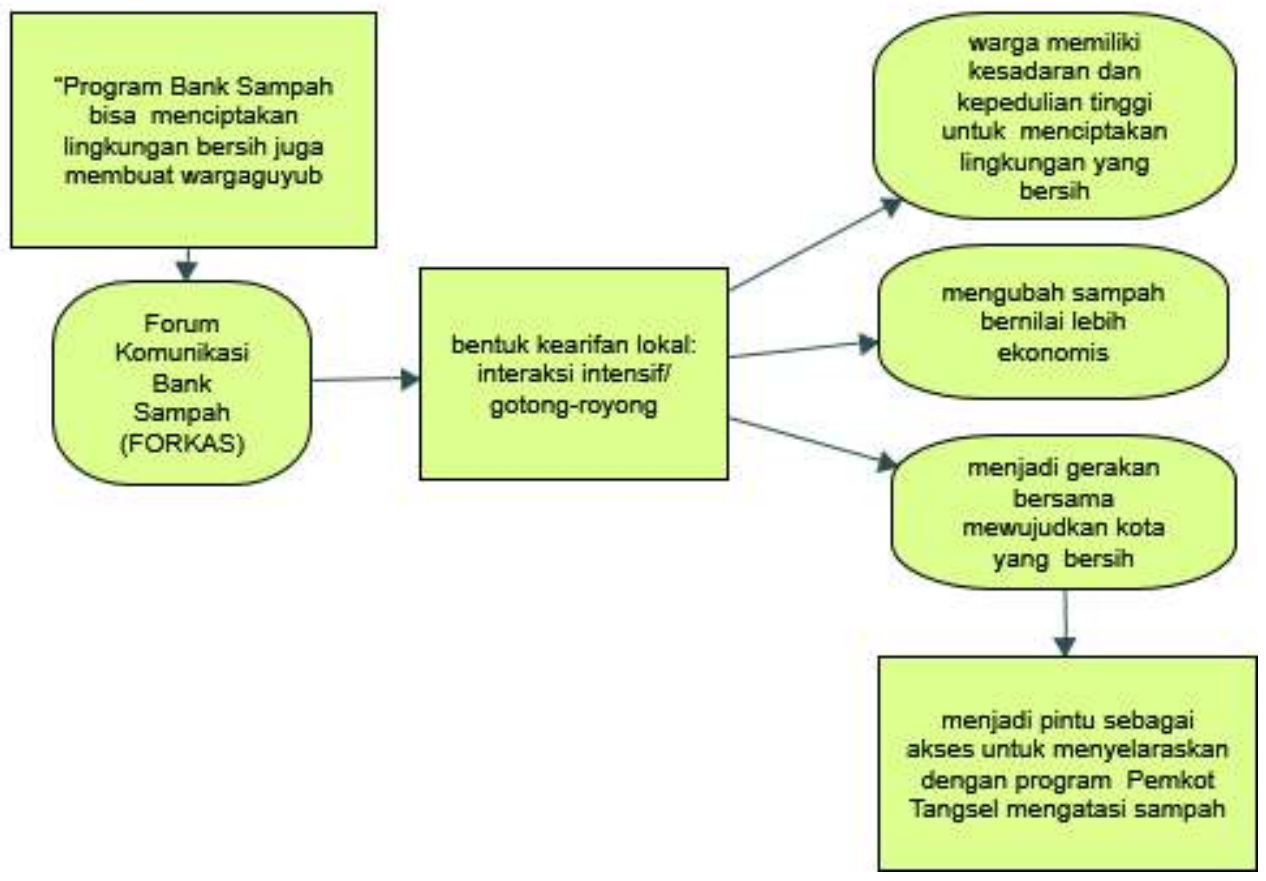

Diagram 5: Gerakan Bank Sampah membuat wargaguyub (diolah dengan software Nvivo 12)

Pada saat di mulai program bank sampah adalah sesuatu yang baru bagi masyarakat, bisa dikatakan program tersebut adalah sesuatu yang disebut inovasi dalam penanganan sampah di Kota Tangerang Selatan pada tahun 2012. Walupun bank sampah pertama kali sudah dimulai di Kota Bantul Yogyakarta pada tahun 2088. jadi kalau kita petakan masyarakat sesuai pemetaan dari Rogers dan Shoemaker (dalam Nasution, 2084), yaitu: 1) Inovator, yakni mereka yang memang sudah pada dasarnya menyenangi hal-hal baru, dan rajin melakukan percobaan-percobaan; 2) Penerima dini (early adopters), yaitu orang-orang yang berpengaruh, tempat temanteman sekelilingnya memperoleh informasi, dan merupakan orang-orang yang lebih maju dibandingkan orang sekitarnya; 3) Mayoritas dini (early majority), yaitu orangorang yang menerima suatu inovasi selangkah lebh dahulu dari rata-rata kebanyak orang lainnya; 4) Mayoritas belakangan (late majority), yakni orang-orang yang baru bersedia menerima suatu inovasi apabila menurut penilaiannya seua orang disekelilinggnya sudah menerima; 5) laggards, yaitu lapisan yang paling akhir dalam menerima suatu inovasi.

Pada kasus ini, inovator adalah yang menggagas atau memelopori, yaitu Pemerintah pusat dan daerah. Sehingga keberadaan tokoh-tokoh masyarakat, komunitas atau kelompok-kelompok swadaya masyarakat adalah sebagai Penerima dini (early adopters), mereka adalah orang-orang yang berpengaruh yang menjadi 
tempat disekeliling orang-orang yang mencari informasi. Sehingga posisi mereka sebagai pintu akses untuk menyelaraskan gerakan bank sampah kepada masyarakat.

\section{Node: Pemerintah Kota}

Pemerintah Kota Tangerang Selatan selain menjalankan amanah mengatasi masalah lingkungan adalah dengan adanya program atau gerakan Bank Sampah yang telah diatur dalam Undang-Undang Republik Indonesia Nomor 18 Tahun 2088 Tentang Pengelolaan Sampah dan Peraturan Pemerintah No 81 tahun 2012, Mengenai Pengelolaan Sampah Rumah Tangga Dan Sampah Sejenis Sampah Rumah Tangga. Disamping itu ada pula motivasi Pemkot Tangerang Selatan, yaitu dalam rangka mempertahankan dan meraih kembali penghargaan Adipura tahun sebelumnya. Maka Bank Sampah diberikan perhatian khusus bahkan ibu Walikota Airin Rachmi Diany menjadi Ketua pembinanya langsung.

Tidak hanya itu, Suhalimi memercayai bank Sampah bisa menjadi salah satu faktor untuk mempertahankan dan meraih kembali penghargaan Adipura untuk Kota Tangerang Selatan (kabartangsel.com, 23 Juli 2013).

"Bank Sampah ini di bawah binaan Dinas Kebersihan Pertamanan dan Pemakaman (DKPP) Kota Tangsel, serta ibu Walikota Airin Rachmi Diany sebagai ketua pembina nya," pungkas Suhalimi (kabartangsel.com, 23 Juli 2013).

Sebagai modal awal, kami berikan modal Rp 5 juta untuk masing-masing Bank Sampah Airaditas," ujar Suhalimi Ismedi, Direktur Bank Sampah Kota Tangsel ketika ditemui saat mengikuti Bimbingan Teknis Bank Sampah, Senin (22/07). Suhalimi mengatakan, tidak hanya modal awal saja yang dikucurkan tetapi masing-masing unit juga akan berikan fasilitas perlengkapan. Sehingga, warga diharapkan sudah bisa langsung mengelolanya (kabartangsel.com, 23 Juli 2013).

Akan jadi percuma jika pemerintah daerahnya memiliki komitmen kuat untuk mengelola sampah tapi masyarakatnya tidak mendukung," kata Walikota Airin saat acara Sosialisasi dan Penyerahan Bantuan Bank Sampah TP PKK di Aula RS Medika BSD, Kecamatan Serpong. Pemerintah Daerah, ungkap Airin, telah membuat kebijakan strategis dalam menangani masalah sampah perkotaan yakni dengan mendirikan Bank Sampah. la telah belajar dan ingin mencontoh dari kesuksesan kabupaten/kota di Malang, Jawa Timur, yang telah berhasil mengembangkan Bank Sampah. Oleh sebab itu, maka setiap per unit Bank Sampah yang ada diberikan bantuan dana permodalan sebesar Rp 5 juta. Dana bantuan ini tahap awalnya diberikan kepada 10 TP PKK yang tersebar di tujuh 
wilayah kecamatan. "Kita berikan bantuan sebesar Rp 5 juta, diharapkan uang ini bisa dipakai untuk mencetak buku tabungan, timbangan dan lain sebagainya," harap Airin (tangseloke.com, 10/9/2013).

Selamat dan Sukses kepada Pemerintah dan Masyarakat Kota Tangerang Selatan atas diraihnya penghargaan Piagam Adipura Kategori Kota Sedang Tahun 2013 "Semoga Kita dapat terus berbenah dalam pengelolaan kebersihan dan lingkungan yang lebih baik menuju Kota Tangerang Selatan yang Mandiri, Damai dan Asri" (bkpp.tangerangselatankota.go.id, 14 November 2013).

Kota Tangerang Selatan (Tangsel) mendapat Penghargaan Piagam Adipura Kategori III (Kota Sedang). Ini sesuai Keputusan Menteri Lingkungan Hidup RI No. 192 Tahun 2013, Tentang Penghargaan Adipura Tahun 2013 tertanggal 3 Juni 2013. Dan kabar menggembirakan ini baru diterima Kepala Badan Lingkungan Hidup Daerah (BLHD) Kota Tangsel Rabu Lalu. Walikota Tangsel sendiri mengaku bersyukur atas diraihnya penghargaan ini bagi Kota Tangsel, namun Airin Juga mengingatkan agar tidak "terlena" dan hendakalah penghargaan ini menjadi langkah awal mengubah perilaku masyarakat untuk lebih mencintai kebersihan dan lingkungan. Karena Tangsel sendiri mempunyai Pekerjaan Rumah (PR) adalah bagaimana mengubah kebiasaan masyarakat agar sadar akan kebersihan (tangsel.xyz, 14 November 2013).

Kepala Bidang Kebersihan pada Dinas Kebersihan Pertamanan dan Pemakaman (DKPP) Kota Tangsel Yepi Suherman mengatakan, volume sampah yang dibuang ke TPA Cipeucang perhari mencapi 160 Ton. Dengan keberadaan bank sampah di tingkat kelurahan diharapkan volume yang harus dibuang ke TPA Cipeucang bisa dikurangi. "Optimis penambahan akan terealisasi. Hanya saja memang banyak kendala," jelas Suherman (kabartangsel.com, 6 Juni 2014).

Airin menyatakan, dalam APBD perubahan 2014, akan disiapkan anggaran bantuan untuk pengelola bank sampah sebesar Rp5 juta. Dana itu nantinya diharapkan menjadi modal untuk para KSM untuk mengelola sampah yang ada. "Sedang disiapkan bantuan Rp 5 juta untuk setiap bank sampah. Itu diharapkan jadi modal untuk pengelolaan," ujarnya (kabartangsel.com, 6 Juni 2014).

Upaya pemerintah Tangerang Selatan untuk memperluas TPA meleset dari target karena terkendala lahan. Target pemerintah daerah membebaskan lahan seluas 10 hektare sejak 2012 tidak membuahkan hasil, karena pemilik lahan menolak tanahnya dibeli. Padahal pemerintah Tangaerang Selatan sudah menganggarkan Rp 35 miliar di APBD. Hasilnya, sejak 2012 hingga 2015, hanya 5,5 hektare yang berhasil dibebaskan (Tempo.co, 23 Agustus 2015). 
Pemerintah Kota Tangerang Selatan menargetkan pembentukan bank sampah hingga akhir tahun mencapai 700 unit, dari sebelumnya yang hanya 130 bank sampah. "Ayo semua aparat kecamatan, termasuk RT dan RW. Setidaknya, satu RW ada bank sampah," kata Kepala Bidang Kebersihan pada Dinas Kebersihan Pertamanan dan Pemakaman (DKPP) Tangsel Yepi Suherman di Ciputat (tempo.co, 30 Maret 2016).

Setelah pada tahun 2013 mendapatkan penghargaan Piagam Adipura, di tahun 2016 ini Kota Tangerang Selatan (Tangsel) meraih Sertifikat Adipura dari Kementerian Lingkungan Hidup dan Kehutanan Republik Indonesia. Penyerahan Sertifikat Adipura tersebut diberikan langsung oleh Menteri Lingkungan Hidup dan Kehutanan Siti Nurbaya kepada Pemerintah Kota Tangsel yang diwakili oleh wakil walikota Benyamin Davnie di Kabupaten Siak dalam acara Peringatan Hari Lingkungan Hidup Sedunia, Jum'at, 22/7/2016 (kabartangsel.com, 24 Juli 2016).

Airin menambahkan jajarannya akan melihat produktivitas antarbank sampah dan TPST. Pertimbangan produktivitas bertujuan untuk memberikan insentif bagi pengurus. "Nanti akan dilihat terlebih dulu sejauh mana kinerjanya. Masukan tentang insentif juga akan kami pelajari," paparnya (tribunnews.com, 21 Agustus 2017).

Dinas Lingkungan Hidup (DLH) Kota Tangerang Selatan mencatat, dari total 208 bank sampah, hanya $50 \%$ yang terbilang aktif. "Padahal program ini sudah dimulai sejak tahun 2013 dan sudah dibentuk di seluruh kecamatan," kata Kabid Persampahan DLH Tangsel, Yepi Suherman, Senin (21/8/2017). Yepi mengatakan, minimnya bank sampah menjadi penyebab Tangsel gagal meraih Piala Adipura. Hal ini kata Yepi akan menjadi evaluasi penting terhadap pengelolaan sampah di Tangsel yang diakui buruk (bantenhits.com, 21 September 2017).

Kegagalan kota Tangerang Selatan dalam mendapatkan piala Adipura tahun 2017 ini menjadi catatan penting bagi Wali Kota Tangsel Airin Rachmi Diany. Untuk itu, Airin telah menargetkan Kota Tangsel pada 2018 untuk meraih Piala Adipura. Agar hal itu tercapai, Dinas Lingkungan Hidup diminta mengoptimalkan peran bank sampah di seluruh wilayah Tangsel. "Tahun ini kita belum berhasil meraih adipura, piagam pun kita belum dapat. Kita ingin bank sampah membantu pemkot meraih Adipura tahun 2018," katanya saat mengahadiri acara silaturahmi pengurus bank sampah di Balaikota Tangsel, beberapa waktu lalu (radartangsel.com, 25 Agustus 2017).

"Pemerintah tidak bisa bekerja sendiri mengatasi sampah perkotaan, butuh peran serta masyarakat. Salah satunya dengan membentuk bank sampah," kata 
Kepala Bidang Persampahan pada Dinas Lingkungan Hidup (DLH) Kota Tangsel, Wisman Syah di Pondok Kacang Timur, Kecamatan Pondok Aren (palapanews.com, 19 Desember 2017).

Setelah membuat urutan secara historical sejak bulan Juli 2013 sampai dengan Desember 2017 data dari pemberitaan media online, maka penulis akan berupaya membuat elaborasi dari semua data diatas dan mengkonstruksi sintesanya dalam sebuah gambar diagram black box sebagai berikut.

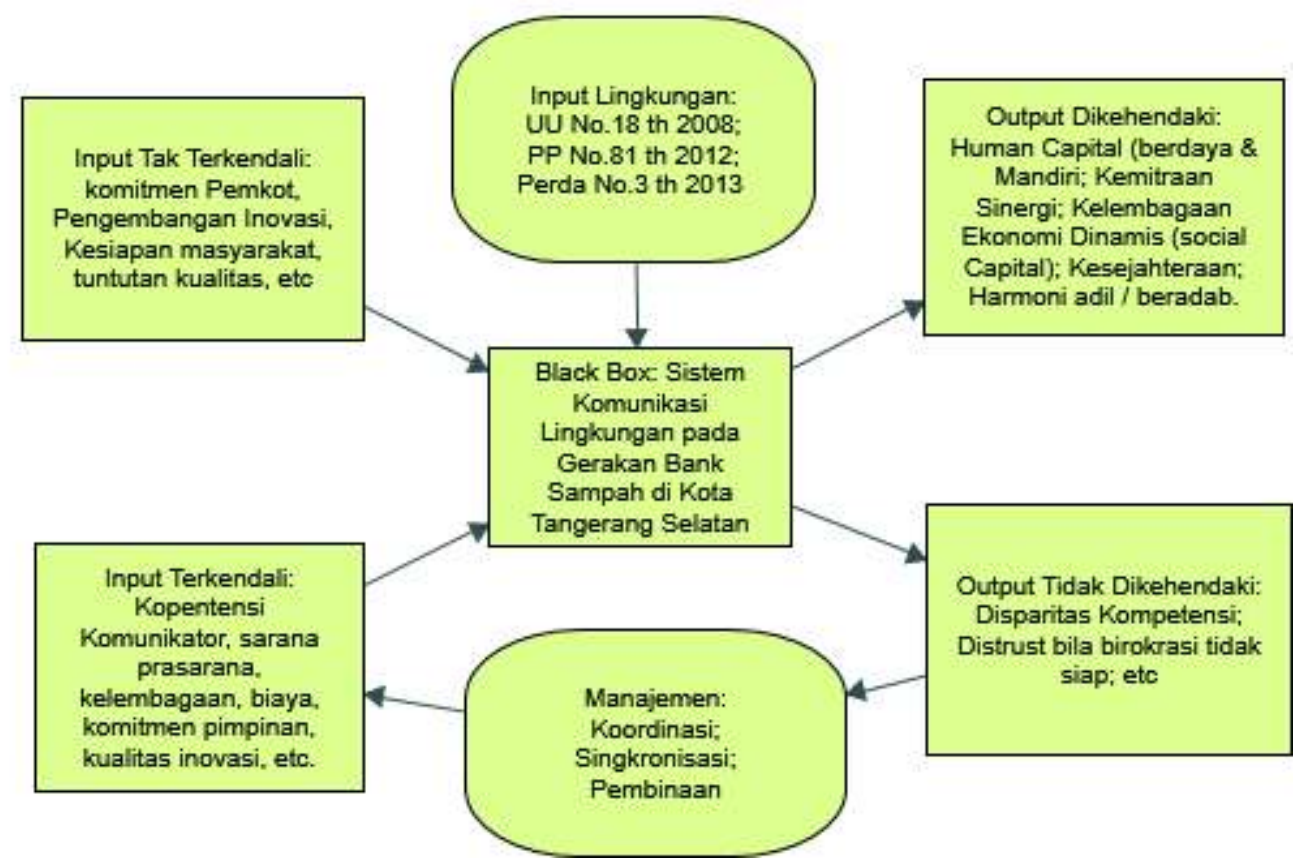

Diagram 6: Analisis Black Box Sistem Komunikasi Lingkungan Gerakan Bank Sampah (diolah dengan software Nvivo 12)

Pada diagram black box diatas menggambarkan sistem komunikasi lingkungan yang dilakukan oleh Pemerintah Kota Tangerang Selatan sebagai Komunikator yang melaksanakan amanah dari Undang-Undang Republik Indonesia Nomor 18 Tahun 2088 Tentang Pengelolaan Sampah dan Peraturan Pemerintah No 81 tahun 2012, Mengenai Pengelolaan Sampah Rumah Tangga Dan Sampah Sejenis Sampah Rumah Tangga. Lalu dibuatlah turunan berupa Peraturan Daerah (PERDA) No.3 Tahun 2013 tentang Pengelolaan Sampah. Input terkedali dari sistem ini adalah kopentensi komunikator yang terlibat seperti Walikota Airin Rachmi Diany langsung sebagai ketua Pembina dari program Bank Sampah di Kota Tangerang Selatan. Awalnya yang menangani masalah Bank Sampah ini adalah Dinas Kebersihan Pertamanan dan Pemakaman (DKPP) Kota Tangsel, dan pada saat penulis melakukan observasi langsung saat ini Dinas Lingkungan Hidup (DLH) Kota Tangerang Selatan juga yang fokus menangani Gerakan Bank Sampah ini. Untuk sarana dan prasarana pemerintah Kota Tangerang Selatan sudah menyiapkan pembinaan dan pelatihan dan juga diberikan berupa modal awal sebesar 5 juta rupiah per satu unit Bank Sampah. 
Komitmen pimpinan juga sebagai Walikota ibu Airin sangat antusias karena di dorong juga dengan motivasi mendapatkan sertifikat Adipura sebagai penghargaan bidang lingkungan hidup yang pernah didapatkan pada tahun 2013 mendapatkan Piagam Adipura Kategori Kota Sedang dan pada tahun 2016 mendapatkan Sertifikat Adipura yang merupakan penghargaan kepada kota/ibukota kabupaten yang mengalami kenaikan nilai Adipura signifikan dibandingkan tahun sebelumnya. Namun, untuk tahun 2017 kota Tangerang selatan tidak mendapatkan satupun penghargaan Adipura. Hal ini menurut Yepi Suherman (Kabid Persampahan DLH Tangsel) dikarenakan tidak aktifnya 50\% dari bank sampah yang sudah berjumlah sekitar 208 unit di 7 Kecamatan. Bank Sampah adalah suatu bentuk inovasi yang biasanya kalau tidak dibuat suatu strategi yang tepat sasaran hasilnya tidak akan bagus, terutama strategi bagaimana mengkomunikasikan kepada masyarakat dan semua pemangku kepentingan yang terlibat.

Selanjutnya dari sisi input yang tidak terkendali adalah terkait komitmen dari komunikator / aktor utama, yaitu Pemerintah Kota Tangerang Selatan itu sendiri bagaimana melalukan pembinaan dan kontrol. Ketidakaktifan dari hampir $50 \%$ bank sampah yang Sudah terbentuk menunjukkan ketidaksiapan masyarakat terkait gerakan bank sampah. Sebenarnya Pemkot Tangsel dapat melakukan studi perbandingan karena tetap ada yang berhasil yaitu $50 \%$ yang aktif bahkan ada diantaranya bank sampah yang sangat produktif seperti bank sampah di RW 08 Kampung Tegalrotan yang dikelola oleh pemuda karang taruna dan murni dibangun atas kesadaran sendiri. Maka perlu mencari akar permasalahannya dulu dan mencari jalan keluar sesuai kondisi yang ada di masing-masing bank sampah. Terkait dengan tuntutan kualitas adalah target yang diinginkan untuk mendapatkan penghargaan Adipura yang merupakan suatu ukuran keberhasilan dibidang lingkungan hidup di Indonesia. Target Pemkot Tangsel pun harus mendapatkan penghargaan Adipura 2018 dengan mengevalusi dan menggerakkan kembali bank sampah yang ada dan mengaktifkan bank sampah vakum. Maka perlu dilakukan mekanisme komunikasi lingkungan yang efektif agar dapat: pertama, membangkitkan kesadaran akan kepedulian terhadap lingkungan hidup. Kedua, menggerakkan semua elemen yang terkait agar dapat Bersama-sama menjadi bagian dari kelestarian lingkungan dengan pesan lingkungan dalam bentuk "bank sampah" yang juga merupakan sebuah sumber ekonomi masyarakat.

Pada sisi output yang diharapkan adalah dapat mewujudkan masyarakat yang mandiri dan berdaya dari sisi kelestarian lingkungan, peduli dan aktif menjaga dan juga dapat berpotensi sumber perekonomian masyarakat. Sinergi antara pemerintah dan masyarakat juga merupakan tujuan yang menunjang keberhasilan dari program gerakan bank sampah ini. Begitu pula perlu membangun jejaring dengan pihak swasta yang berpotensi juga membantu dari kegiatan CSR nya. Lalu dengan pihak akademisi yang bisa jadi membantu dari sisi pendampingan, penyuluhan, pelatihan dan hal yang terkait dengan inovasi teknologi lingkungan yang mendukung gerakan bank sampah. Selanjutnya, yang menjadi tujuan utama dari gerakan ini menciptakan kesejahteraan bagi masyarakat yang terlibat sehingga dapat menghilangkan kesenjangan dengan 
masyarakat ekonomi yang sudah mapan. Ada sinergi, keharmonisan, tidak ada persaingan kelas ekonomi, yang sebagian besar penggerak atau pelaku dari gerakan bank sampah ini adalah kalangan menengah kebawah.

Sementara output yang tidak diharapakan adalah seperti yang sudah dipaparkan sebelumnya, yaitu kegagalan meraih Adipura di tahun 2017, disparitas (perbedaan) kompetensi terutama dari para komunikator/ aktor yang terlibat, seperti dari Pemkot Tangsel itu sendiri yang tidak begitu secara rutin melakukan kontrol dan evaluasi. Bisa terjadi suatu penurunan yang sangat membahayakan adalah bila terjadi hilangnya kepercayaan (distrust) dari masyarakat umum terhadap kinerja pemerintahan kota. Akhirnya setelah melakukan evaluasi dari kelemahan yang ada maka perlu melakukan pengaturan kembali (manajemen) untuk menata posisi atau langkah-langkah apa saja yang mungkin terlewatkan dan melakukan terobosanterobosan yang tepat sasaran. Hal pertama yang dilakukan kembali berkoordinasi dengan komunikasi yang efektif dimana pesan yang disampaikan oleh pengirim dan penerima pesan menghasilkan kebutuhan yang sama (singkronisasi). Komunikator lingkungan yang utama disini adalah Pemerintah Kota Tangerang Selatan yang akan berkoordinasi dan berkomunikasi keseluruh pemangku kepentingan serta yang lebih khusus kepada sasaran pemberdayaan yaitu masyarakat dengan terus melakukan pembinaan dan pendampingan sampai tahap kemandirian. Semua lapisan masyarakat harus menjadi bagian dari gerakan bank sampah ini, kelas atas bisa memberikan sarana prasarana dana modal usaha termasuk ikut membaur dalam kebersamaan menjaga lingkungan hidup Bersama.

\section{Node: Swasta}

Dalam upaya melaksanan program atau gerakan bank sampah diperlukan kerjasama jejaringan, tidak bisa bekerja sendiri-sendiri. Maka seluruh pemangku kepentingan harus dilibatkan mulai dari pemerintah kota melalui Dinas-dinas yang terkait seperti Dinas Lingkungan Hidup (DLH) atau bisa juga Dinas Koperasi dan Usaha Mikro Kecil Menengah (UMKM) karen Bank Sampah merupakan gerakan hybrid, yaitu gerakan sosial, lingkungan dan juga ekonomi. Otomatis perlu diikuti secara sinergi oleh seluruh aparatur dan perangkat pemerintahan mulai dari Kecamatan sampai dengan tingkat RT dan RW, lalu pihak swasta seperti perusahaan-perusahaan yang ada dilingkungan, dari sisi akademisi atau institusi pendidikan, yaitu sekolah dan perguruan tinggi, kelompok swada masyarakat, forum-forum rutin di masyarakat dan tentunya peran serta (partisipasi) dari masyarakat pada umumnya. Kegiatan yang riil perlu dilakukan seperti kutipan dibawah ini.

Pertemuan yang dihadiri oleh sekitar 300 orang penggiat Bank Sampah tersebut diselenggarakan oleh Pemerintah Kota Tangerang Selatan bekerjasama dengan Yayasan Bunga Melati Indonesia, dan didukung oleh berbagai institusi termasuk diantaranya Bank Artha Graha Internasional. 
Kehadiran Bank Artha Graha Internasional dalam kegiatan tersebut merupakan salah satu wujud peranan kongkrit lembaga jasa keuangan dalam mengintegrasikan unsur lingkungan, sosial dan tata kelola dalam menerapkan prinsip-prinsip keberlanjutan dalam praktek perbankan. Bank Artha Graha Internasional merupakan satu diantara 8 Bank yang ditunjuk oleh Otoritas jasa Keuangan (OJK) dalam pilot project "First Steps to be Sustainable Bank". Selain itu, Bank ini juga telah ditunjuk oleh Pemerintah dalam penyaluran program Kredit Usaha Rakyat. Kegiatan tersebut sekaligus merupakan peran serta Bank Artha Graha Internasional dalam pelaksanaan edukasi perbankan kepada masyarakat sebagai salah satu kegiatan yang digagas oleh OJK selama bulan Oktober 2016 yaitu Gerakan Inklusi Keuangan Untuk Semua "Geraiku" (arthagraha.com, 13 October 2016).

Pada tahun 2016, Yayasan Pelangi yang merupakan mitra LSM AQUA Grup mulai melakukan pendampingan untuk memberdayakan Bank Sampah Mekarsari. Atas dukungan AQUA Grup sebagai fasilitator, Yayasan Pelangi kembali menjalankan sosialisasi tentang pentingnya bank sampah kepada masyarakat. Yayasan Pelangi juga melakukan pendampingan terhadap pengurus bank sampah untuk mengelola operasional bank sampah termasuk mengembangkan sistem pengumpulan sampah yang lebih efektif. Perubahan yang paling krusial adalah terbukanya akses Bank Sampah Mekarsari untuk menjual secara langsung sampah botol plastik dan cup pada Recycling Business Unit (RBU) di Tangerang Selatan milik AQUA Grup (aqualestari.aqua.com, 3

\section{Maret 2017).}

Sebagai contoh pihak swasta yang punya potensi bermitra dengan bank sampah adalah semua perusahan yang memang berkepentingan terkait limbah hasil dari produksi masal, seperti perusahaan air mineral AQUA yang pasti menghasilkan limbah plastik yang pasti cukup banyak setiap harinya karena memang pasti dikonsumsi banyak tiap harinya. Mereka juga berkepentingan sebagai tanggung jawab sosial yang mengharuskan mereka ikut aktif berperan serta menangani limbah plastik. Dari data diatas adalah salah satu bentuknya AQUA Grup sebagai fasilisator bermitra dengan Yayasan Pelangi yang sama-sama melakukan pendampingan dan supporting kepada pengurus bank sampah dalam rangka mengelola operasioanal dan juga pengembangan sistem pengumpulan yang efektif.

Disamping itu pula, hampir semua perusahaan swasta/ korporat mempunyai kewajiban mengadakan pendanaan atau mengadakan kegiatan yang bersifat sosial, yaitu program Corporate Social Responsibility (CSR) yang bisa diajak untuk bekerja sama dalam menangani gerakan bank sampah. 


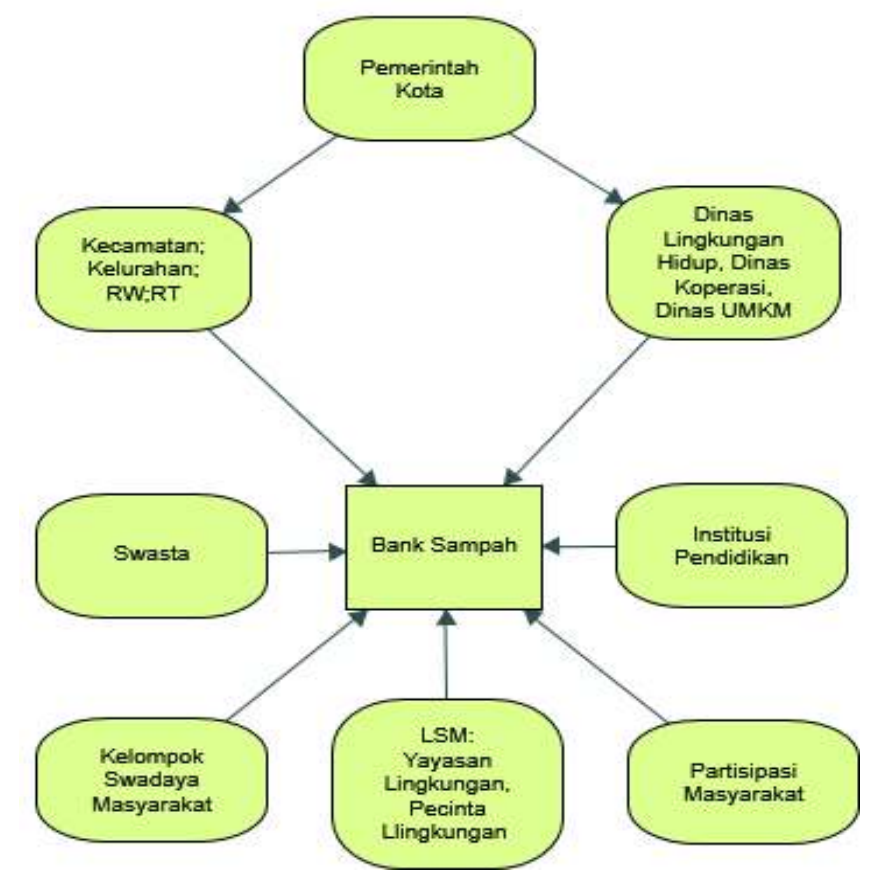

Diagram 7: Jejaring stakehouder yang diharapkan dari Gerakan Bank Sampah (diolah dengan software Nvivo 12)

\section{Node: Tokoh Masyarakat}

Untuk memastikan setiap gerakan atau suatu upaya yang mengarah kepada perubahan sosial, perubahan perilaku maka dibutuhkan seorang agen perubahan (agent of change) atau opinion leader yang dengan pengaruhnya dapat menggerakkan masyarakatnya.

Ditempat sama, Ketua Bank Sampah Kota Tangerang Selatan, Tutu S Indra, menjelaskan, pada kesempatan acara ini dimanfaatkan pihaknya untuk meluncurkan program Bank Sampah sekaligus menginformasikan sisi manfaat ekonomisnya. "Kita ingin masyarakat lebih antusias untuk mengatasi sampah di Tangsel agar Tangsel menjadi kota yang bersih dari sampah," jelasnya. Manfaat dari Bank Sampah ini, tambah Tuti, hendaknya juga disampaikan (tangseloke.com, 10 September 2013).

Koordinator Bank Sampah Kecamatan Ciputat Dimas Wiwoko mengatakan, kehadiran bank sampah adalah bentuk kearifan lokal. Sebab sejak dini warga memiliki kesadaran dan kepedulian tinggi untuk menciptakan lingkungan yang bersih. Selain mengubah sampah bernilai lebih ekonomis, bank sampah juga menjadi gerakan bersama mewujudkan kota yang bersih (metro.sindonews.com, 2 Juni 2017). 


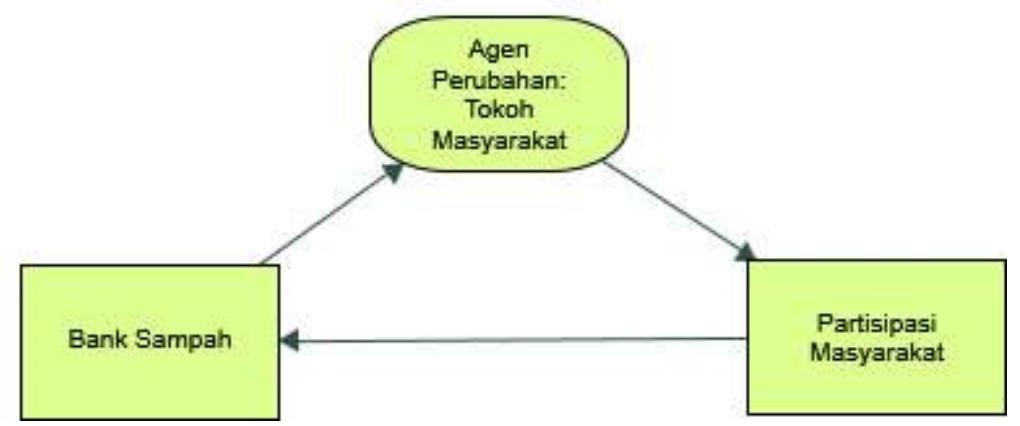

Diagram 8: Peran agent of change untuk menggerakkan partisipasi masyarakat (diolah dengan software Nvivo 12)

Namun, biasanya yang menjadi penggerak (agent of change) rata-rata adalah tokoh-tokoh yang sangat berpengaruh dan selalu menjadi panutan. Potensi kendala yang akan dihadapi adalah bila ketergantungan dengan satu figur, bila saat figur tersebut tidak ada maka akan selesai juga gerakan atau kegiatan. Perlu dilakukan kaderisasi dan regenerasi untuk meneruskan pola-pola kebiasaan yang sudah dibangun. Terlebih penting juga yang mengambil peran sebagai agen perubahan haruslah semua pihak dari semua pemangku kepentingan yang telah dipaparkan sebelumnya. Bila hanya ada pola saling mengandalkan dalam arti negatif, hal ini juga akan menjadi kendala dalam masalah keberlanjutan kegiatan gerakan Bank Sampah.

\section{Code: Lokasi}

Pemerintah Kota Tangerang Selatan (Tangsel) menargetkan setiap Rukun Warga (RW) memiliki bank sampah. Dari 400 bank sampah yang ditargetkan, baru 88 unit yang teralisasi. "Kami menargetkan setiap RW mempunyai bank sampah di Kota Tangsel, " kata Wali Kota Tangsel Airin Rachmi Diany. Kendala yang kerap dihadapi dalam membangun bank sampah terangnya soal keberadaan lahan dan juga kesiapan warga menjadi pengelola sampah-sampah tersebut (kabartangsel.com, 6 Juni 2014).

Sebelas bank sampah itu akan ditempatkan di 11 kelurahan. Antara lain Kelurahan Lengkong Wetan, Rawa Mekar Jaya, Bakti Jaya, Pondok Benda, Benda Baru, Cempaka Putih, Serua, Sawah, Pondok Jagung Timur, Jurang Wangu Barat, dan Pondok Betung (kabartangsel.com, 23 Juli 2013).

Agar mampu meraih adipura, bank sampah dan TPST yang ada harus melakukan pemilahan sampah secara tepat. Sehingga, sampah-sampah yang nantinya dibuang ke TPA Cipeucang hanya sampah yang tidak bisa dimanfaatkan kembali. "Jadi yang dibuang ke TPA hanya residunya saja. Yang bisa dimanfaatkan dan bernilai ekonomi dikelola di TPST atau bank sampah," imbuh Yepi (radartangsel.com, 25 Agustus 2017). 
Bertempat di Universitas Terbuka, Pondok Cabe, Tangerang Selatan, pada hari Kamis, 13 Oktober 2016 berlangsung pertemuan dalam rangka motivasi \& evaluasi Bank Sampah Melati Bersih - Kota Tangerang Selatan dan Kabupaten Tangerang tahun 2016 (arthagraha.com, 13 October 2016).

Bank sampah terakhir yang diluncurkan adalah berada di Cluster Sudimara Jombang (CSJ), Kelurahan Jombang, Ciputat. Di cluster ini, sampah-sampah yang telah dipilah warga kemudian langsung ditimbang untuk dijual (metro.sindonews.com, 2 Juni 2017).

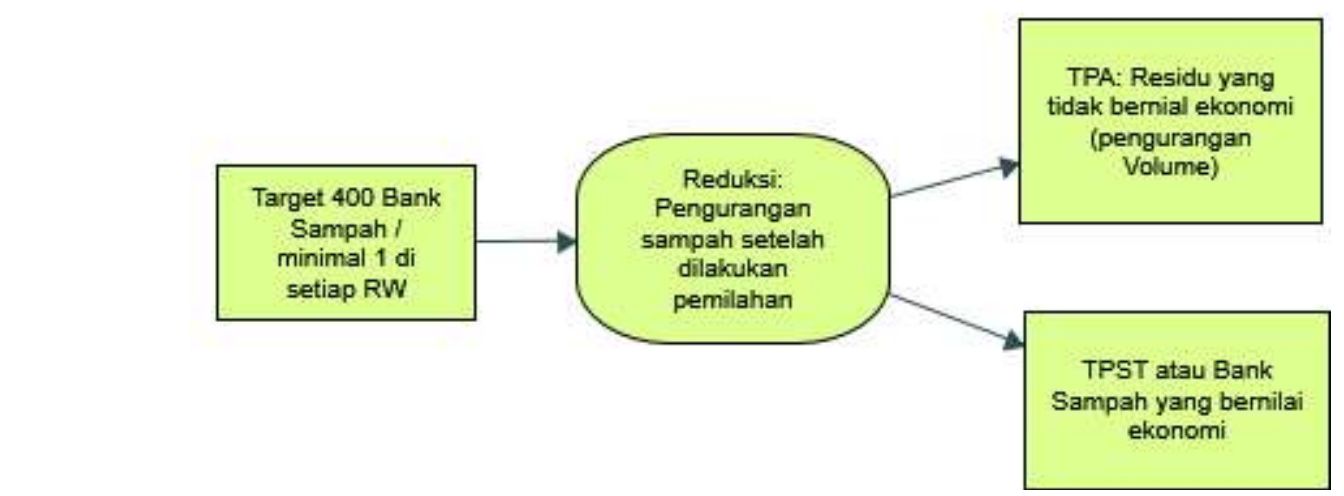

Diagram 8: Penguraian sampah mengurangi volume TPA dan menjaring manfaat ekonomis (diolah dengan software Nvivo 12)

Diagram 8 mengambarkan bahwa gerakan bank sampah sudah mampu mengurai sampah sehingga terjadi pengurangan volume sampai ke TPA yang memang kapasitasnya sangat terbatas, walaupun memang belum signifikan. Perlu penguatan kembali terhadap gerakan bank sampah karena untuk menciptakan kebiasaan baru perlu konsistensi dan terus berkolaborasi dengan berbagai kalangan, harus juga ada proses enkulturasi, yaitu bagaimana ide, gagasan, kebiasaan, budaya, program seperti memilah sampah mulai dari rumah tangga dilakukan kepada generasi penerus, anak-anak yang masih muda belia dan bahkan sejak usia dini sudah diperkenalkan. Memang membutuhkan waktu dan proses yang terus berkelanjutan.

\section{Code: Pemberdayaan Masyarakat}

\section{Node: Pengembangan Budaya}

Sedikit demi sedikit perubahan perilaku masyarakat untuk sadar lingkungan dan kreatif sudah mulai terasa dan memiliki hasil nyata. Pada akhirnya juga dapat mengubah pandangan masyarakat bahwa sampah bukanlah musibah. Sampah akan menjadi berkah apabila disikapi dengan baik dan bijak (news.detik.com, 19

Mei 2017). 
Sampah Tangsel 880 Ton Setiap Hari Di Pilah, Gerakan tersebut yakni masyarakat memilah dan memanfaatkan sampah. Yepi gencar melakukan gerakan bank sampah di lingkungan Kota Tangerang Selatan sejak tahun 2012. Hingga kini jumlah dari bank sampah yang sudah terbentuk dan aktif yaitu 202 bank sampah. Jumlah nasabah dari bank sampah se-Kota Tangerang Selatan kurang lebih 4.000 anggota. Langkah - langkah inovasi Yepi merangsang masyarakat untuk dapat mengelola sampah di Kota Tangsel. Masyarakat menjadi gemar menanam dengan memanfaatkan kompos organik dan menggunakan wadah tanam dari barang barang bekas yang ada. Sedikit demi sedikit perubahan perilaku masyarakat untuk sadar terhadap lingkungan dan kreatif sudah mulai terasa dan memiliki hasil nyata. Pada akhirnya juga dapat mengubah pandangan masyarakat bahwa sampah bukanlah musibah. Sampah akan menjadi berkah apabila disikapi dengan baik dan bijak. "Karapkannya keterlibatan masyarakat sebagai mitra dinas lingkungan hidup Kota Tangerang Selatan dengan berperan aktif dan berpartisipasi pada Bank Sampah dapat membantu mewujudkan kota yang sehat, indah, bersih dan kreatif," ujar Yepi (tangselbanget.com, 19 Mei 2017).

“Dengan adanya bank sampah ini, kami ingin mendidik generasi muda betapa penting kesehatan di lingkungan ini. Kami memiliki target agar nasabah bisa sejahtera dengan adanya bank sampah RW 08 ini," beber Iwan (bidiktangsel.com,23 Januari 2018).

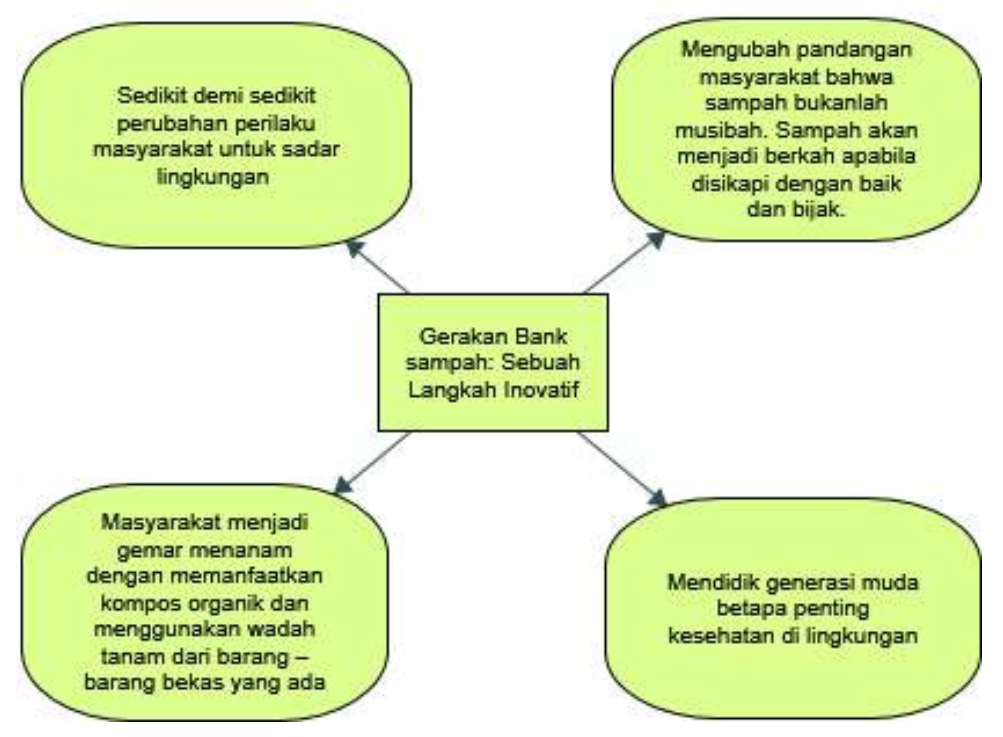

Diagram 8: Manfaat Bank Sampah dalam merubah perilaku dan pandangan (diolah dengan software Nvivo 12) 
Setelah mengelaborasikan dari data dengan tema pengembangan budaya maka dapat digambarkan bagaimana posisi bank sampah dalam merubah, menanamkan kebiasaan baru untuk peduli terhadap lingkungannya. Sekalipun belum semua masyarakat terlibat dalam gerakan bank sampah ini, tapi sudah terlihat adanya perubahan sedikit demi sedikit dan mengubah pandangan terhadap sampah bukanlah musibah atau sesuatu tanpa arti, tapi bisa dikondisikan menjadi sesuatu yang bernilai ekonomis. Kegiatan ini bisa memecahkan beberapa permasalahan sosial, lingkungan hidup dan juga masalah ekonomi masyarakat. Bila dikelola dengan professional dan melibatkan pihak-pihak yang mempunyai kekuatan akses dan permodalan, bisa saja dikembangkan menjadi lapangan pekerjaan baru sehingga disamping menyelesaikan masalah lingkungan juga dapat mengurangi penganguran.

Selain itu karena mulai ada kebiasaan baru, yaitu memilah sampah dan sering bertemu untuk kepentingan lingkungan, ternyata ada kebiasaan baru yaitu kegemaran untuk menanam pohon. Hal tersebut dikarenakan disamping memilah sampah yang masih bernilai ekonomis ada sampah yang diolah menjadi pupuk kompos. Dari pengkomposan masih bisa dijual lagi dan bila tidak digunakan untuk memberi pupuk dikebun pekarangan bisa dihalaman sendiri atau lokasi-lokasi yang biasa dipakai untuk pertemuan saat pengumpulan sampah yang masih bernilai ekonomis. Saat ini memang masih didominasi oleh ibu-ibu rumah tangga yang memang sudah terbiasa secara rutin ada kegiatan dilingkungan tempat tinggal, seperti majlis ta'llim, posyandu sehingga berdasarkan data yang diperoleh oleh penulis saat observasi pra penelitan. Tapi ibuibu yang memang aktif secara tidak langsung memberikan suatu teladan bagi yang belum berpartisipasi dan juga kepada generasi muda agar sedini mungkin dibiasakan seperti memilah sampah yang ternyata sebuah kontribusi untuk menyelamatkan alam dari kerusakan yang dampaknya memang tidak secara langsung. Maka perlu menanamkan budaya bersih, peduli lingkungan agar dapat menjadi budaya yang positif dan tetap konsisten dilaksanakan secara keberlanjutan.

\section{Node: Pengembangan Ekonomi}

Walikota Airin mengatakan, pihaknya akan terus mendorong kelompok bank sampah lainnya mengikuti program serupa. Warga diajak untuk bisa memanfaatkan potensi pengolahan sampah perkotaan menjadi lahan garapan produktif. Jenis tanaman yang bisa dikembangkan pun banyak (kabartangsel.com, 10 Juli 2015).

\footnotetext{
"Misalkan harga cabe lagi mahal, kan saya kalau beli. Kalau menanam sendiri itu jauh lebih hemat," ungkapnya di lokasi panen raya, Kamis, 9 Juli 2015. Walikota Airin menyarankan warga, hendaknya untuk sementara ini jenis komoditi yang ditanam tidak terlalu banyak (kabartangsel.com, 10 Juli 2015).
} 
Alasannya, jika terlalu banyak maka dikhawatirkan tidak akan efektif. Menurut Walikota Airin, meski sedikit asalkan efektif dan tepat sasaran jauh lebih baik. Apalagi jika bisa berkembang pesat. Setidaknya mampu mencukupi untuk kebutuhan bagi warga kelompok bank sampah. "Kalau nanti memang sudah lebih untuk kebutuhan sehari-hari ya terserah ibu kalau mau dijual ya silahkan. Tapi tahap awal buat konsumsi pribadi saja dulu," terangnya (kabartangsel.com, 10 Juli 2015).

“Dari hasil pengembangan, sudah dilakukan sebanyak 50 anggota bank sampah yang sudah menguji coba menanam caisim dengan menggunakan pupuk organik yang sudah dikemas dalam kantong plastik," jelasnya (kabartangsel.com, 10 Juli 2015).

Ditambahkannya, dari sampah sangat banyak manfaat yang bisa dikembangkan, bukan hanya dimanfaatkan sampah yang bisa dipilah untuk dijual seperti botol, kaleng dan benda-benda keras lainya seperti besi dan tembaga. Namun juga sampah organis menjadi kompos yang sangat subur dan bermanfaat bagi tanaman Pola inilah yang harus dikembangkan dan terus disosialisasikan kepada masyarakat (kabartangsel.com, 10 Juli 2015).

"Semua harus dimanfaatkan agar keberadaan sampah bukan hanya yang dibuang ke Tempat Pembuangan Akhir (TPA) tapi bagaimana bisa menghasilkan nilai ekonomis yang tinggi," tambahnya (kabartangsel.com, 10 Juli 2015).

Selama ini sampah selalu dipahami sebagai suatu benda yang tidak berguna. Namun kini sampah tengah naik daun. Sampah tidak lagi dipandang picik sebelah mata, karena ternyata memiliki nilai ekonomis yang cukup tinggi ketika dikelola oleh orang-orang yang kreatif (kabartangsel.com, 23 Juli 2013).

Metode penanganan sampah dengan membangun bank sampah diharapkan bisa menjadi budaya di masyarakat Kota Tangsel. Masyarakat juga diharapkan bisa lebih pandai memilah sampah organik dan non organik dan memungsikannya ke dalam tabungan (kabartangsel.com, 23 Juli 2013).

Untuk pengambilan uang hasil tabungan, nasabah bisa mengambilnya setiap tiga bulan sekali agar manfaat besarnya bisa dinikmati (kabartangsel.com, 23 Juli 2013). 
Dalam kesempatan itu, Pemkot Tangsel juga membuka masukan beragam kendala dari pengurus bank sampah, serta akan melihat produktivitas antar bank sampah dan tempat pembuangan sampah terpadu (TPST). Pertimbangan produtivitas itu dimaksudkan untuk nantinya memberikan insentif bagi pengurus (radartangsel.com, 25 Agustus 2017).

Di sisi lain, optimalisasi bank sampah juga sangat berpotensi secara ekonomi. Sebab, Yepi mengungkapkan, dari 100 bank sampah, tercatat telah memiliki aset tabungan sampah yang jika dinominalkan mencapai Rp 1,7 miliar. "Rp 1,7 miliar itu diakumulasikan dari 100 bank sampah dalam kurun waktu 4 tahun didirikan bank sampah," tambahnya (radartangsel.com, 25 Agustus 2017).

Keterlibatan semua elemen masyarakat untuk mau mengelola sampah dari sumbernya, menurut dia sangat penting. Kelompok warga bisa membentuk bank sampah di setiap lingkungan RW dengan memanfaatkan sampah menjadi bernilai ekonomis. "Pengelolaan sampah secara terpadu melalui kelompok bank sampah bisa mendongkrak nilai tambah pertumbuhan ekonomi berbasis masyarakat," ungkapnya (palapanews.com, 19 Desember 2017).

Keseriusan Yepi membuahkan hasil. Setiap bank sampah dapat memilah sampah dari sumbernya dan membuat sampah memiliki nilai ekonomi (news.detik.com, 19 Mei 2017).

la mengaku dalam program ini juga menggandeng pihak Dinas Koperasi dan UKM Kota Tangerang Selatan untuk mau menampung hasil pengumpulan dan olahan sampah organik serta non-organik untuk selanjutnya dipasarkan (tangseloke.com, 10/9/2013).

Keseriusan dari Yepi membuahkan hasil. Setiap bank sampah dapat memilah sampah dari sumbernya dan membuat sampah memiliki nilai ekonomi yang berarti. Kehadiran bank sampah sangat efektif karena ada pelibatan warga secara aktif sejak dini. Harapannya volume sampah yang sampai di Cipeucang berkurang dan sifatnya sudah tak bernilai ekonomis lagi (tangselbanget.com, 19 Mei 2017).

"Hanya 100 bank sampah saja yang ada laporannya. Kami bentuk itu di tujuh Kecamatan yang ada di Tangsel," ujar Yepi pada Senin (21/8/2017). Yepi menjelaskan, optimalisasi bank sampah ini sangat berpotensi secara ekonomi (metro.sindonews.com, 2 Juni 2017). 
Dari 100 bank sampah yang aktif, tercatat telah memiliki aset tabungan sampah yang jika dinominalkan bisa mencapai Rp. 1,7 miliar. "Dana sebesar Rp. 1,7 miliar itu diakumulasikan dalam kurun waktu empat tahun," ucapnya (tribunnews.com, 21 Agustus 2017).

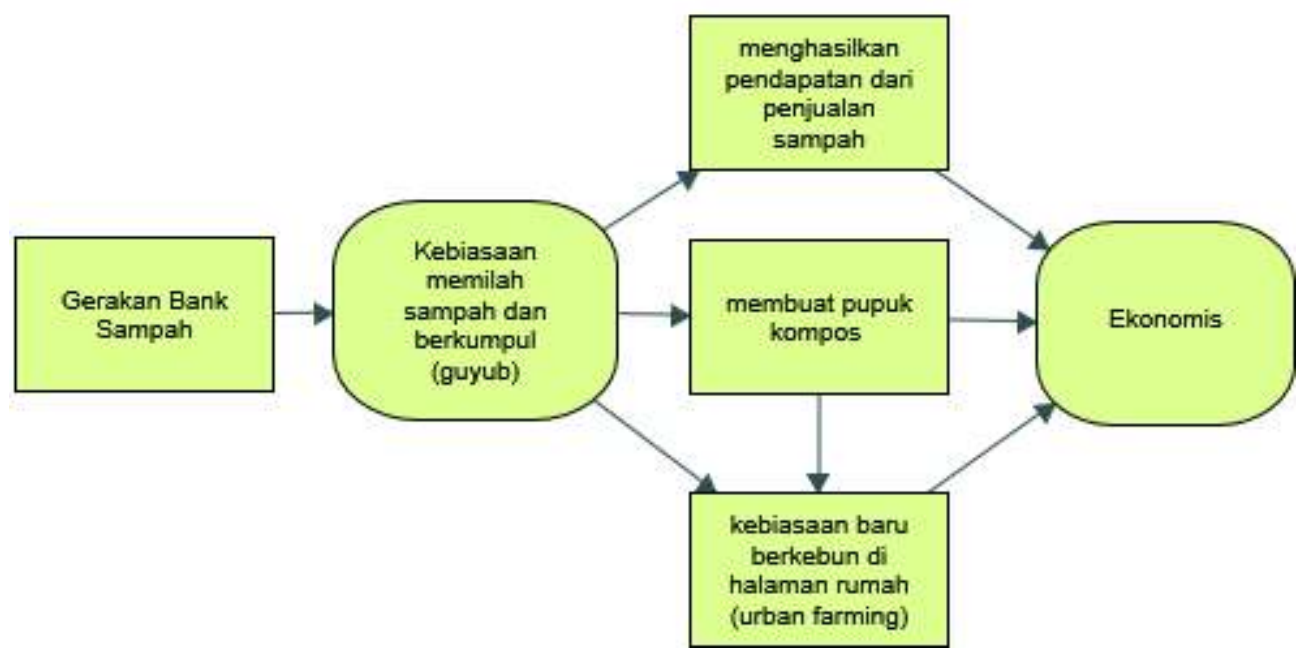

Diagram 9: Manfaat Bank Sampah secara ekonomis (diolah dengan software Nvivo 12)

Dari hasil pengembangan budaya yang telah dipaparkan diagram 9 sebenarnya sudah merupakan gambaran karena adanya kebiasaan memilah sampah, akhirnya jadi memunculkan kebiasaan baru, yaitu membuat kompos yang akhirnya diikuti dengan kebiasaan menanam pohon atau berkebun. Ada memang dorongan berupa profit dari mengumpulkan dan menabungnya di bank sampah. Ada temuan di pra penelitian, yaitu di lokasi Bank Sampah Berlian di daerah Pamulang Tangerang Selatan, bahwa kebanyakan ibu-ibu rumah tangga yang aktif, dan bahkan ada yang menjadi kebiasaan mengumpulkan sampah plastik disekitar lingkungan yang bukan sampah dari rumahnya sendiri. Sekalipun ada saja bahasa negatif seperti, "kok jadi kayak pemulung $y a^{\prime \prime}$, tapi itu tidak dihiraukan. Di lokasi tersebut memang terjadi pembaruan antara warga kelas atas, menengah dan bawah secara ekonominya dalam kegiatan bank sampah. 


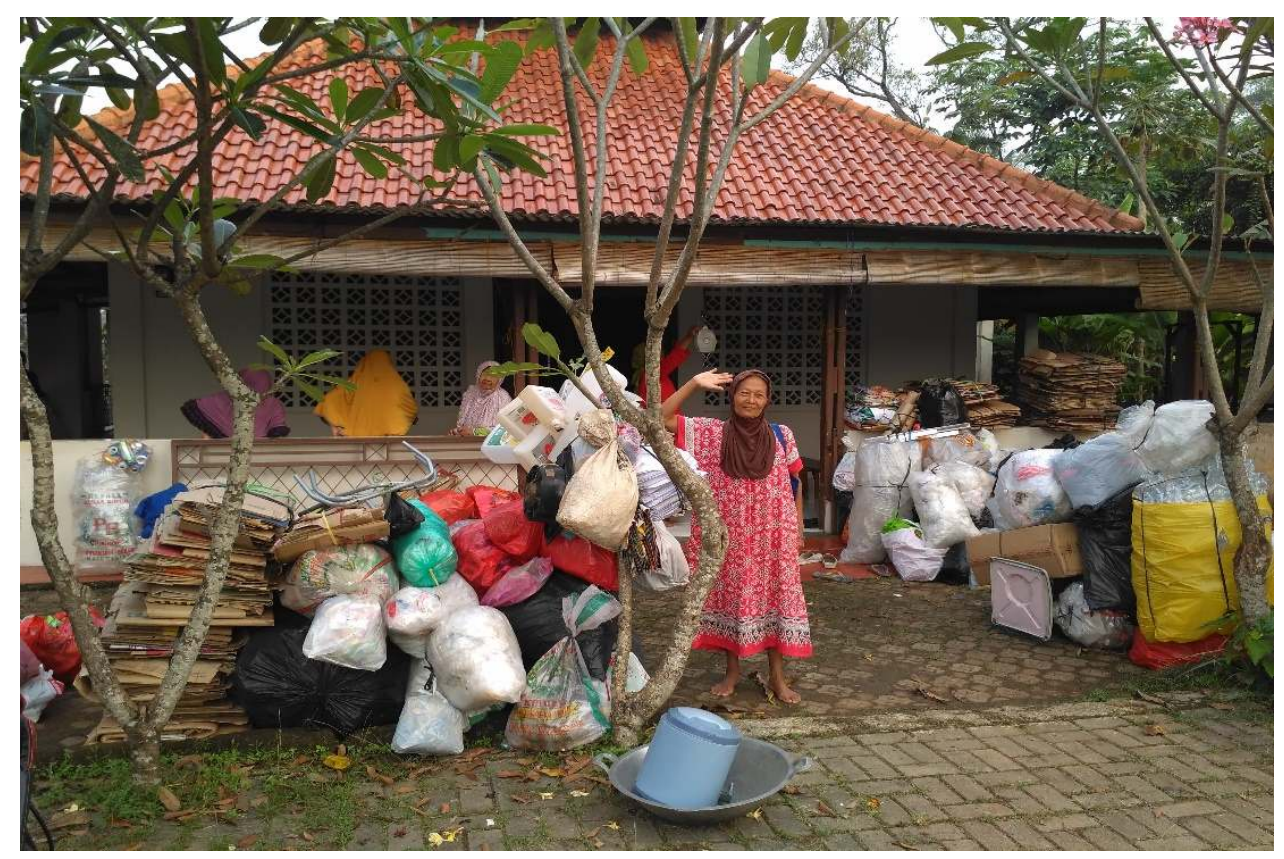

Gambar1: lokasi pengumpulan Bank Sampah Berlian di Jl. Cemara 1 Pamulang Barat, Tangerang Selatan (dokumen penulis, 19 April 2018)

\section{Node: Pengembangan Lingkungan}

Menurut Suherman, dengan keberadaan 88 unit bank sampah yang ada di Kota Tangsel saat ini sudah cukup membantu. Dengan adanya bank sampah tersebut, volume sampah yang harus di buang ke TPA Cipeucang dapat dikurangi (kabartangsel.com, 6 Juni 2014).

Di lokasi yang sama, Kepala Bidang Kebersihan pada Dinas Kebersihan Pertamanan dan Pemakaman (DKPP) Kota Tangerang Selatan - Yepi Suherman menjelaskan, wilayah ini memiliki karakter perkotaan yang tidak lepas dari keberadaan penduduk yang dulunya petani. Oleh karenanya, sekarang ini pemerintah daerah termotivasi untuk mendorong warga mau memanfaatkan lahan menjadi produktif (kabartangsel.com, 10 Juli 2015).

Walikota Airin mengatakan, pihaknya akan terus mendorong kelompok bank sampah lainnya mengikuti program serupa. Warga diajak untuk bisa memanfaatkan potensi pengolahan sampah perkotaan menjadi lahan garapan produktif. Jenis tanaman yang bisa dikembangkan pun banyak (kabartangsel.com, 10 Juli 2015). 
Langkah-langkah inovasi Yepi merangsang masayarakat untuk mengelola sampah. Masyarakat menjadi gemar menanam dengan memanfaatkan kompos organik dan menggunakan wadah tanam dari barang-barang bekas (news.detik.com, 19 Mei 2017).

"Harapannya keterlibatan masyarakat sebagai mitra dinas lingkungan hidup kota Tangsel dengan berperan aktif dan berpartisipasi pada bank sampah dapat membantu mewujudkan kota yang sehat, indah, bersih dan kreatif," ujar Yepi (news.detik.com, 19 Mei 2017).

Sebab, di Karang Taruna RW 08 Kampung Tegalrotan itu, sampah yang belakangan ini kerap ditemukan ditepi jalan dan disaluran-saluran air milik warga, kini nyaris tak lagi dijumpai. Hal ini lantaran sampah-sampah yang terdiri dari bahan non organik tersebut, kini ditampung di bank sampah yang dikelola Karang Taruna setempat (bidiktangsel.com,23 Januari 2018).

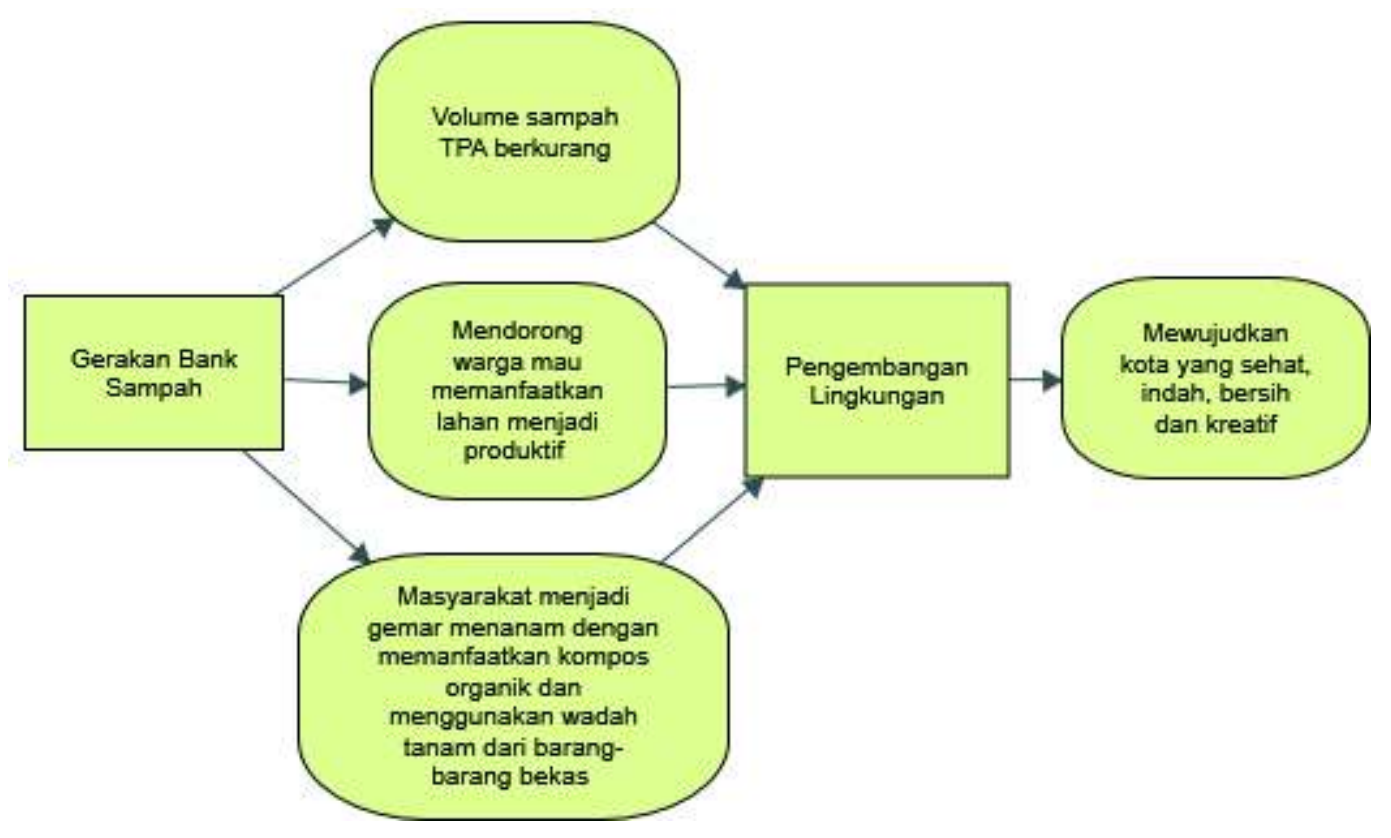

Diagram 10: Manfaat Bank Sampah secara pengembangan lingkungan (diolah dengan software Nvivo 12)

Berdasarkan diagram 10 dapat digambarkan bahwa gerakan bank sampah telah mampu mendorong warga memanfaatkan lahan menjadi produktif. Disamping dapat berdampak pengurangan volume sampah yang akan dikirim ke Tempat Pembuangan Akhir (TPA), masyarakat jadi gemar untuk menanam dengan memanfaatkan kompos organik dan juga memanfaatkan barang-barang bekas (reuse) sebagai wadah tanamannya. Dari aktivitas tersebut dapat disimpulkan bahwa telah 
terjadi pemberdayaan masyarakat dari sisi dimensi pengembangan lingkungan sesuai dengan konsep dimensi pemberdayaan masyarakat Jim Ife (2016).

\section{Node: Pengembangan Personal/ Spiritual}

Lebih lanjut Suhalimi menerangkan pengelola bank sampah nantinya yang akan bertanggung jawab kepada setiap masyarakat yang akan menabungkan sampahnya (kabartangsel.com, 23 Juli 2013).

Dari hasil yang diperoleh, sekian banyak tanaman yang dipanen, ini menandakan adanya kemauan masyarakat untuk berkreasi. Tentunya ini menjadi hal yang sangat menggairahkan untuk dikembangkan. Terlebih media pupuk organik yang digunakan untuk bertanam, tentunya ini memberikan pelajaran bahwa sampah sangat bermanfaat bila dikembangkan (kabartangsel.com, 10 Juli 2015).

Menurutnya, untuk membuka Bank Sampah tidak perlu banyak modal karena tinggal menyiapkan sumber daya manusia untuk mengelola bank sampah tersebut (bisnis.tempo.co, 30 Maret 2016).

Sampah Tangsel 880 Ton Setiap Hari Dikelola, Yepi juga membina dan mendukung setiap Bank Sampah yang sudah terbentuk. Dia juga memberikan suatu bimbingan teknis tentang bagaimana manajemen bank sampah dijalankan, daur ulang dan urban farming. Selain hal itu pemenuhan kelengkapan aktivitas masing - masing dari bank sampah seperti timbangan sampah, buku tabungan nasabah dan neon box sebagai identitas bank sampah (tangselbanget.com, 19 Mei 2017).

"Kesadaran warga dalam mengelola sampah sudah semakin baik. Ini bisa membantu pemerintah mengatasi persoalan sampah," ujar Ketua Forum Komunikasi Bank Sampah (Forkas) Tangsel Eka Meidya, Kamis, 1 Juani 2017 kemarin (metro.sindonews.com, 2 Juni 2017).

Masyarakat juga menjadi kreatif berkreasi membuat barang - barang dari hasil pemilahan sampah. Dengan gerakan tersebut maka akan semakin menambah manfaat seperti mengedukasi masyarakat tentang proses komposting sampah sampah organik (tangselbanget.com, 19 Mei 2017).

Yepi membina dan mendukung setiap Bank Sampah yang sudah terbentuk. Dia juga memberikan bimbingan teknis tentang manajemen bank sampah, daur ulang dan urban farming. Selain itu pemenuhan kelengkapan aktivitas masing-masing 
bank sampah seperti timbangan sampah, buku tabungan nasabah dan neon box sebagai identitas bank sampah (palapanews.com, 19 Desember 2017).

Di lokasi yang sama, Kepala Seksi Kemitraan dan Pemberdayaan Masyarakat DLH Kota Tangsel, Ahmad Rivai mengungkapkan belakangan ini masyarakat sangat antusias untuk terlibat langsung sebagai mitra pemerintah deaerah. Banyak kelompok warga mau bergabung sebagai nasabah bank sampah maupun pembentukan bank sampah baru (palapanews.com, 19 Desember 2017).

Iwan mengungkapkan, tahap awal pembentukan Bank Sampah di RW 08, sedikitnya terdapat 22 nasabah ikut berpartisipasi menabungkan sampah yang dikelola Karang Taruna. Sedangkan untuk penimbangan sampah rumah tangga mulai dari kemasan gelas dan botol air mineral, majalah, sepeda anak bekas serta kardus, disetorkan sekali dalam seminggu (bidiktangsel.com,23 Januari 2018).

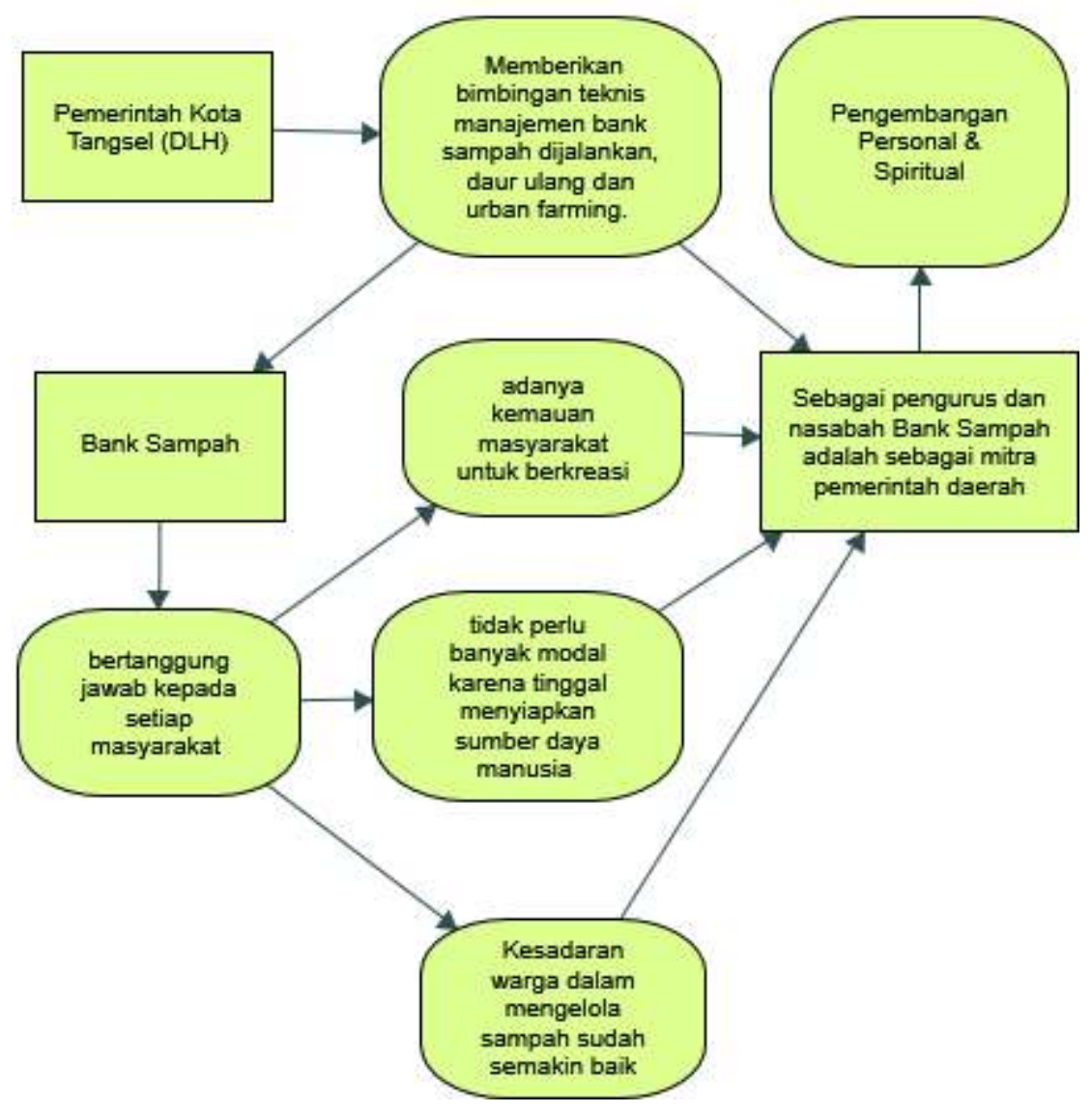

Diagram 11: Manfaat Bank Sampah secara pengembangan personal dan Spiritual (diolah dengan software Nvivo 12) 
Pengembangan personal masyarakat meliputi: perkembangan personal (personal growth) dan pengembangan personal (personal development) dan pengembangan spiritual bertujuan untuk memberikan makna terhadap kehidupan masyarakat menjadi lebih baik dan berharga (ife, 20816). Pengembangan individu dalam pengembangan masyarakat menjadi penting, yaitu untuk memenuhi kebutuhan individu melalui jaringan dan interaksi dalam masyarakatnya, ketimbang melalui profesionalisme dan kesuksesan pribadi. Saat kita bergaul dengan aktivitas positif akar terjadi pertukaran pengalaman, ilmu dan apapun sehingga akan meningkatkan pengembangan secara personal menjadi pribadi yang bisa bermasyarakat, menerima kekurangan orang lain dan bahkan siap memberi, melengkapinya.

Dengan gerakan bank sampah bisa melatih pengembangan empati diri, peduli dengan sesama dan lingkungan sekitarnya. Ada juga temuan beberapa orang yang menyerahkan sampah yang bernilai ekonomis dengan niat di sumbangkan tanpa perlu dicatat di buku tabungannya. Di sisi spiritual nya jelas pada saat kita melakukan tanggung jawab sosial, ingin memberikan manfaat kepada sesama manusia, sesama makhluk hidup maka kita sedang berinteraksi dengan sang Pencipta untuk mengaktualisasikan rasa syukur kita atas semua karunia yang diberikan-Nya.

\section{Node: Pengembangan Politik}

Terkait dengan pengembangan politik menurut ife (2016), ada dua dimensi yaitu internal dan ekternal. Internal terkait dengan kesadaran individu terkait pentingnya masalah politik atau kebijakan legal hasil keputusan sistem politik di suatu bangsa atau negara berpengaruh dengan kondisi ekonomi, budaya dan karakter bangsanya. Jadi bila memilih menjadi apolitic (menjauh dari dunia politik) sama saja kita akan membiarkan kekuasaan jahat berkuasa. Dari sisi ekternal bisa berupa aksi sosial, karena kita tidak mungkin berdiam dengan kondisi yang tersandera, tidak berdaya karena suatu ketimpangan misalnya disebabkan birokrasi politis tidak bisa berbuat terhambat karena suatu regulasi. Misalnya sampah sudah sangat mengotori lingkungan pemukiman, tapi tidak diperhatikan oleh petugas yang berwenang, maka aksi sosial merupakan bentuk pengembangan kepekaan politik secara mikro.

Tangerang Selatan gagal meraih penghargaan Adipura dan menjadi evaluasi penting dalam mengelola permasalahan sampah. "Tahun ini kami belum berhasil meraih Adipura, piagam pun belum dapat. Kami ingin bank sampah dapat 
membantu Pemkot dan masyarakat pada umumnya," ungkap Wali Kota Tangerang Selatan, Airin Rachmi Diany (tribunnews.com, 21 Agustus 2017).

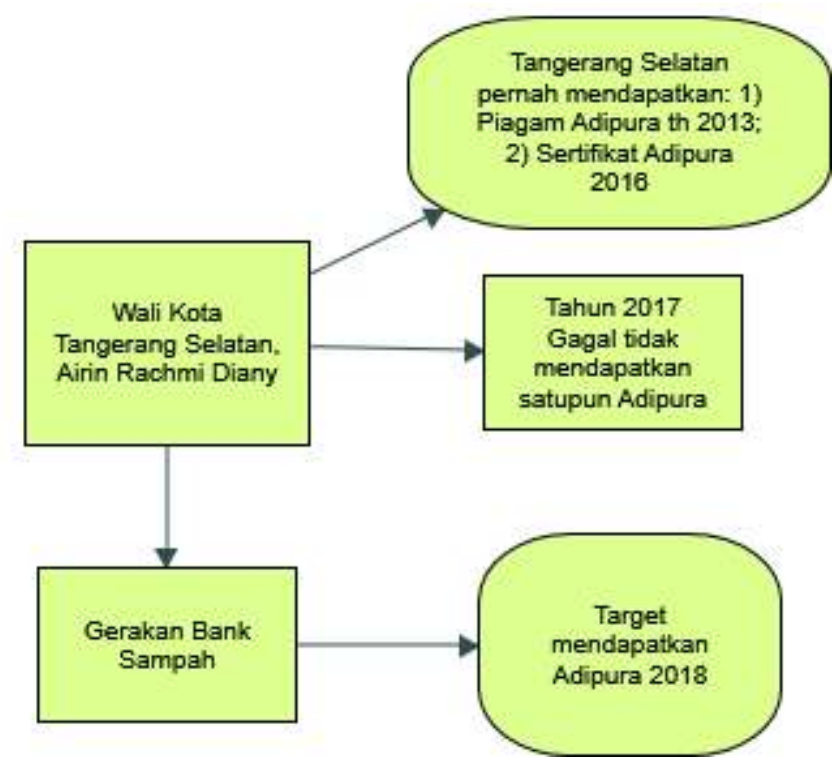

Diagram 11: Ada Harapan Bank Sampah membantu untuk memperoleh Adipura 2018 (diolah dengan software Nvivo 12)

Dari sisi pengembangan politik, dari data yang didapat bahwa masih merupakan kepentingan Pemerintah Kota Tangerang Selatan terkait dengan target memperoleh penghargaan Adipura. Dengan adanya keinginan dari Pemkot Tangerang Selatan, maka akan ada upaya untuk mengorganisasian masyarakat (community organizing) agar bergerak lebih maksimal. Sementara disisi masyarakat juga mendapatkan keuntungan dari sisi ekonomisnya. Misi untuk gerakan lingkungan yang berdampak pada mobilisasi sosial memang membutuhkan kekuatan politik untuk melegitimasi dan sebagai pemberi kekuatan untuk mendorong dari sisi spirit dan juga material. Pola hubungan yang saling mengisi kekosongan seperti hubungan simbiosis mutualisme.

\section{Node: Pengembangan Sosial}

“Nanti akan dilihat dulu sejauh mana kinerjanya, masukan tentang insentif itu juga akan kita pelajari, karena pengelola bank sampah juga kebanyakan kader PKK. Boleh atau tidaknya menjalankan tugas ganda," ujar Airin yang juga Ketua Partai Golkar DPD Kota Tangsel (radartangsel.com, 25 Agustus 2017).

Warga Tangerang Selatan (Tangsel) didorong berperan aktif menanggulangi masalah sampah. Salah satunya, dengan membentuk bank sampah di lingkungan masing-masing (palapanews.com, 19 Desember 2017). 
Wisman bilang, pihaknya tak bosan terus berupaya dapat menggugah dan menarik minat masyarakat untuk mengelola sampah. Langkah kebijakan tersebut sesuai dengan program Pemkot Tangsel (palapanews.com, 19 Desember 2017).

Gerakan ini yakni masyarakat memilah dan memanfaatkan sampah. Yepi gencar melakukan gerakan bank sampah di lingkungan kota Tangsel sejak 2012. Sampai saat ini jumlah bank sampah yang sudah terbentuk dan aktif yaitu 202 bank sampah. Jumlah nasabah bank sampah se-Tangsel kurang lebih 4.000 orang (news.detik.com, 19 Mei 2017).

Masyarakat juga menjadi lebih kreatif berkreasi membuat barang-barang dari hasil pemilahan sampah. Dengan gerakan bank sampah semakin menambah manfaat seperti mengedukasi masyarakat tentang proses komposting sampahsampah organik (news.detik.com, 19 Mei 2017).

Manfaat dari Bank Sampah ini, tambah Tuti, hendaknya juga disampaikan para kader ke seluruh warganya (tangseloke.com, 10/9/2013).

Usut punya usut, rupanya pemuda dikawasan tersebut memiliki motivasi agar Tegalrotan terbebas dari sampah yang suatu saat bisa saja menimbulkan berbagai penyakit. Hal itupun dibenarkan oleh Iwan, pentolan Karang Taruna Sawah Baru saat berlangsungnya peresmian operasional bank sampah oleh Dinas Lingkungan Hidup (DLH) Kota Tangsel (bidiktangsel.com,23 Januari 2018).

"Visi saya ingin Kampung Tegal Rotan bersih dan sehat. Dan saya ingin mengajak generasi muda peduli akan lingkungan," kata Iwan menjelaskan kepada wartawan dilokasi, kemarin (bidiktangsel.com,23 Januari 2018).

Ditempat yang sama, Kepala Bidang Persampahan pada DLH Kota Tangsel, Wisman Syah mengapresiasi keberadaan bank sampah di RW 08 Kampung Tegalrotan yang saat ini dikelola Karang Taruna. "Saya sangat mengapresiasi. Karena bank sampah itu didirikan murni atas inisiatif sendiri dari rekan-rekan Karang Taruna Sawah Baru," ujarnya (bidiktangsel.com,23 Januari 2018).

Di lokasi ini, ketinggian sampah pun sudah mencapai belasan meter. Namun di tengah kondisi tersebut, tumbuh harapan persoalan sampah perlahan bisa teratasi karena animo warga untuk membuat bank sampah juga tinggi (metro.sindonews.com, 2 Juni 2017). 
Hingga kini, jumlah bank sampah di kota seluas 147,19 km persegi ini sudah mencapai 208. Nasabahnya pun telah mencapai 4.000 orang lebih. Tingginya kesadaran warga ini, diyakini mampu membantu mengatasi persoalan sampah (metro.sindonews.com, 2 Juni 2017).

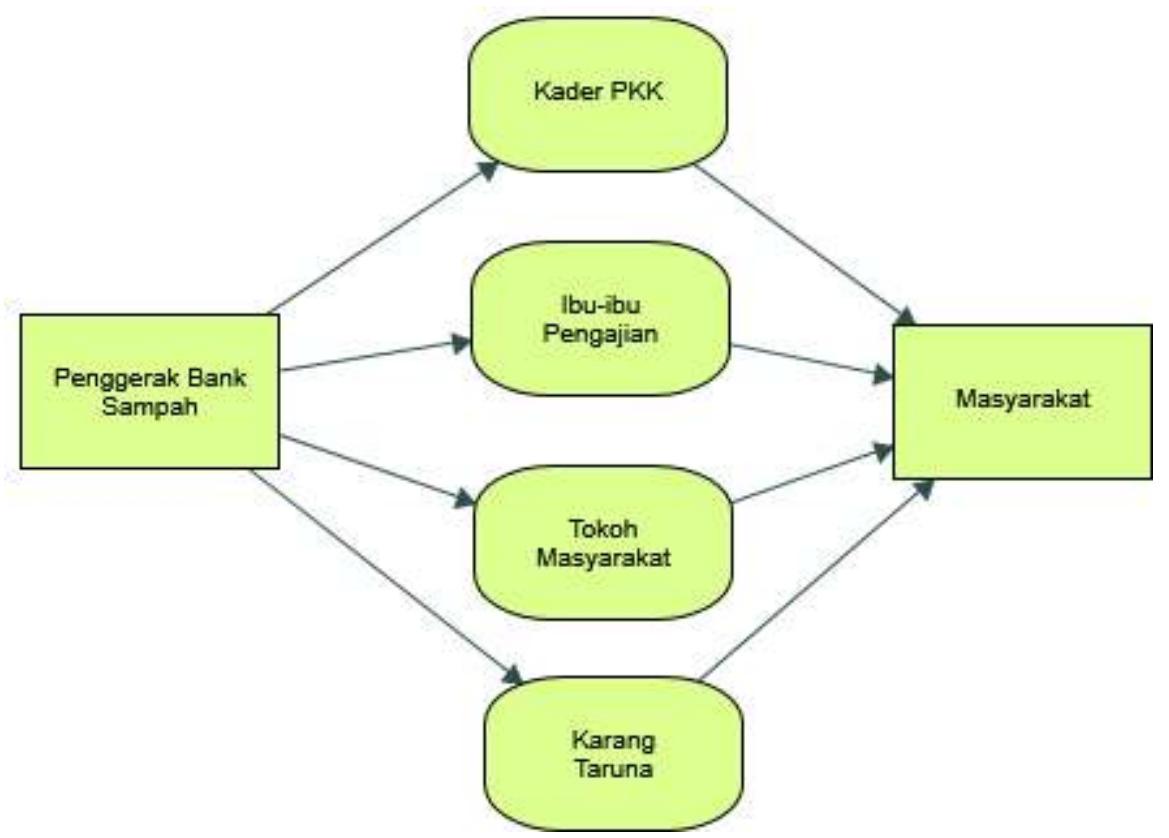

Diagram 11: Penggerak Bank Sampah untuk pengembangan sosial (diolah dengan software Nvivo 12)

Dari sisi pengembangan sosial dengan adanya bank sampah akhirnya memunculkan komunikator/ aktor penggerak masyarakat. Adanya pusat kegiatan yagn menjadi sarana berkumpul dan berinteraksi, dan adanya praktek kegiatan perencanaan sosial seperti pembentukan kepengurusan, penentuan prioritas kegiatan di lingkungan masyarakat. Semua dapat meningkatkan interaksi antaranggota masyarakat, sehingga mereka memiliki perasaan kolektivitas dan kesiapan untuk berpartisipasi untuk membangun, dan menjaga lingkungan mereka sendiri.

\section{Code: Pesan Lingkungan}

Persoalan sampah memang masih menjadi persoalan pelik bagi kota-kota di Indonesia. Tak terkecuali bagi Kota Tangerang Selatan sebagai kota yang tengah berkembang pesat (kabartangsel.com, 23 Juli 2013).

Sampah menjadi salah satu permasalahan kota Tangerang Selatan (Tangsel). Tangsel menghasilkan sampah kurang lebih 880 ton setiap hari. Dalam keterangan tertulis dari Dinas Lingkungan Hidup Pemkot Tangsel, Jumat (19/5/2017), Kepala 
Bidang Persampahan dari Dinas Lingkungan Hidup Pemkot Tangsel, Yepi Suherman, berfikir keras untuk menanggulangi sampah. Yepi mencetuskan dan perkenalkan program bank sampah kepada masyarakat (news.detik.com, 19 Mei 2017).

Saat ini sampah sudah menjadi salah satu permasalahan yang serius di Kota Tangerang Selatan ini. Kota Tangerang Selatan menghasilkan sampah kurang lebih 880 Ton setiap harinya. Dalam keterangan tertulis dari Dinas Lingkungan Hidup Pemkot Tangerang Sealtan (tangselbanget.com, 19 Mei 2017).

Volume sampah di Kota Tangerang Selatan (Tangsel) setiap harinya tergolong besar karena mencapai 880 ton. Pemkot Tangsel kian dihadapkan persoalan pelik karena saat ini baru memiliki satu Tempat Pemprosesan Akhir Sampah, yakni di Cipeucang, Serpong (metro.sindonews.com, 2 Juni 2017).

Kota Tangerang Selatansat ini mengalami persoalan terkait pengelolaan sampah. Hal itu diungkapkan langsung Kepala Bidang Persampahan Dinas Lingkungan Hidup Tangerang Selatan, Yepi Suherman. la menjelaskan, dari 208 bank sampah yang dibentuk, hanya 50 persen yang saat ini masih aktif. Padahal program tersebut sudah digalakkan sedari tahun 2013 silam (tribunnews.com, 21 Agustus 2017).

Pengelolaan sampah di Tangerang Selatan ini pun terbilang buruk. Yepi mengungkapkan pihaknya akan melakukan pemilihan sampah secara tepat. Hal itu dilakukan agar sampah - sampah yang terbuang dapat dimanfaatkan kembali. Makanya harus diadakan bank sampahdan tempat pembuangan sampah terpadu (TPST) (tribunnews.com, 21 Agustus 2017).

"Jadi yang dibuang ke TPA (tempat pembuangan akhir) hanya residunya saja, yang bisa dimanfaatkan dan bernilai ekonomi dikelola di TPST atau bank sampah," kata Yepi. Minimnya bank sampah tersebut berdampak pada raihan Adipura pada tahun ini (tribunnews.com, 21 Agustus 2017). 


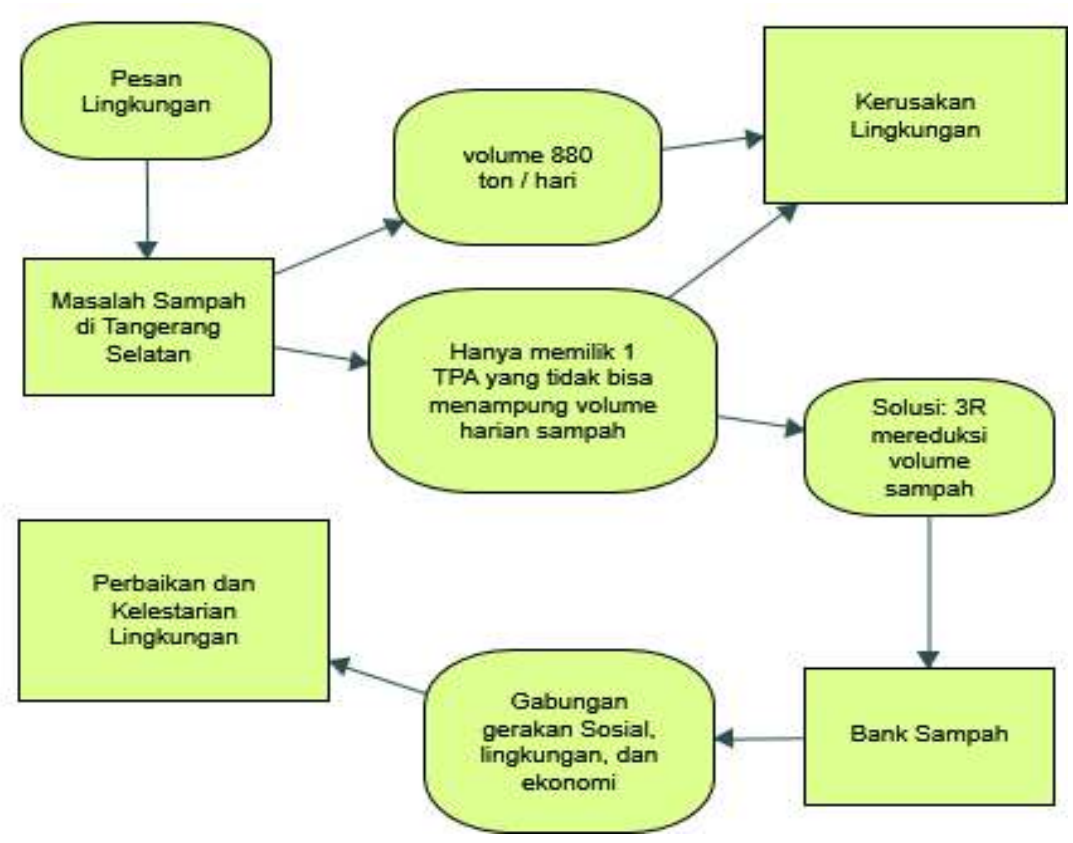

\section{Diagram 12: Permasalahan sampah dan solusi Bank Sampah sebagai Pesan Lingkungan}

(diolah dengan software Nvivo 12)

Pengembangan lingkungan sudah sangat jelas adalah upaya untuk memperbaiki lingkungan secara menyeluruh bukan hanya skala khusus, walaupun sampah menjadi sentral konsentrasi. Tetapi permasalahnya tidaklah sesederha itu, bagaimana sampah bisa dikendalikan dan berdampak sosial, lingkungan, dan ekonomi. Pengembagan lingkungan memerlukan penyadaran masyarakat tentang pentingnya memahami keterkaitan lingkungan (makro) dengan kehidupan manusia, dalam skala global yang akan berdampak lokal. Kalau berpikirnya parsial maka misi lingkungan akan tersendat-sendat dan fluktuatif. Maka fokusnya dalam pengembangan lingkungan adalah seperti penyadaran, Pendidikan, pengorganisasian masyarakat, perencanaan, dan seterusnya agar selalu melekat menjadi cara pandang yang selalu untuk menjaga, memperbaiki lingkungan yang memang sudah sangat kuat diterjang oleh arus modernisasi dan industrialisasi yang terkadang mengabaikan dampak negatif lingkungan.

\section{Code: Saluran Komunikasi Lingkungan}

Pantauan di lapangan seperti yang dilansir laman resmi website Pemerintah Kota Tangsel tangerangselatankota.go.id, hasil nyata ini langsung disaksikan oleh Walikota Airin Rachmi Diany memetik sejumlah pejabat daerah yang turut menghadiri acara panen raya. Orang nomor satu di kota termuda Provinsi Banten 
ini ikut memetik daun caisim hijau yang ditanam oleh kelompok warga sekitar (kabartangsel.com, 10 Juli 2015).

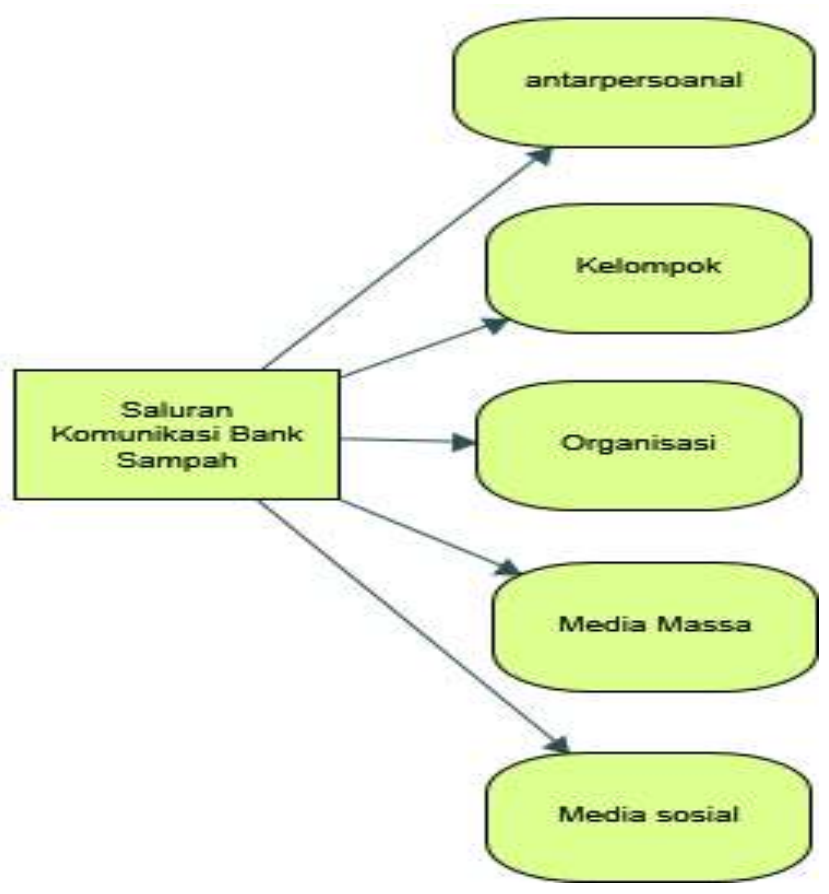

Diagram 13: Media/ saluran yang digunakan dalam gerakan Bank Sampah (diolah dengan software Nvivo 12)

Dari data yang diproleh dari kliping online, penulis belum maksimal mendapatkan data terkait penggunaan media yang digunakan dalam berinteraksi. Namun, hanya satu terkait penggunaan media sosial atau web yang menjadi sarana komunikasi dengan audiens/ masyarakat yang mau berinteraksi terkait masalah bank sampah. Ada beberapa bank sampah yang memiliki akun facebook, twitter, path, youtube, dan juga ada beberapa peliputan berita tentang bank sampah di situs berita online tapi memang tidak begitu gencar, mungkin karena isu lingkungan tidak begitu menarik perhatian khalayak dibandingkan dengan misalnya berita isu politik apalagi menjelang pesta demokrasi seperti saat ini di tahun 2018. Ini menjadi catatan untuk menggali lebih dalam saat turun laparngan penelitian selanjutnya. 


\section{Diagram Komplilasi Secara Keseluruhan}

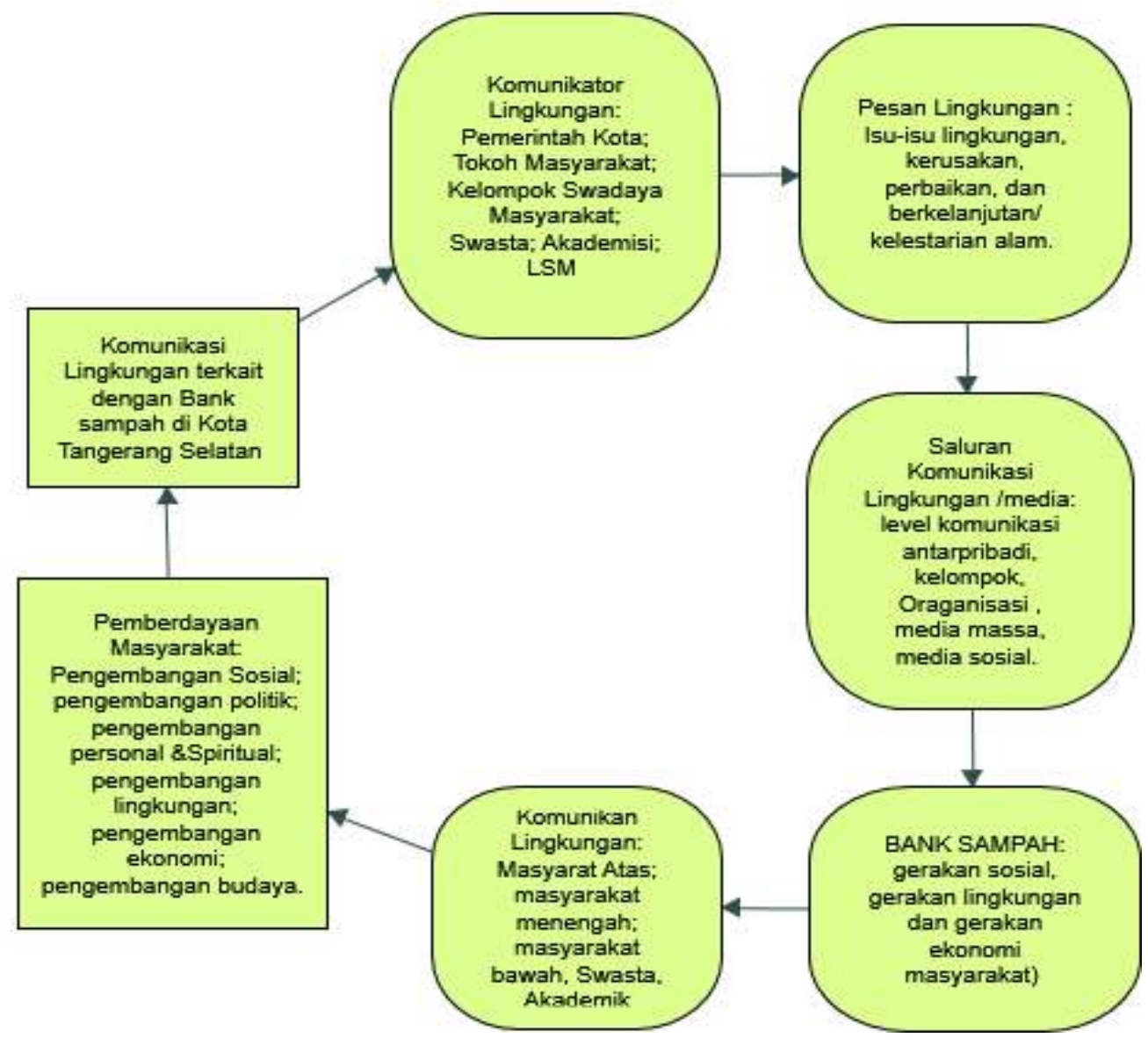

Diagram 14: Menggambarkan Sistem atau pola komunikasi Lingkungan pada Bank Sampah di Kota Tangerang Selatan dalam upaya pemberdayaan masyarakat (diolah dengan software Nvivo 12)

Lingkungan (environment) bisa bermakna sebuat sistem dimana adanya suatu tatanan kehidupan yang terdiri dari komponen-komponen yang saling berinteraksi dan saling tergantungan dalam menjaga keseimbangan untuk mempertahankan keberlangsungan sebuah siklus kehidupan khususnya lingkungan yang ada di bumi. Lingkungan atau ekosistem di bumi secara garis besar ada dua unsur, yaitu unsur abiotik, materi yang tidak hidup dan bergerak tapi mempunyai sifat-sifat dan karakter yang bisa berinteraksi dengan mahluk hidup dan unsur biotik adalah mahluk hidup, dimana ada esensi kehidupan yang ada di dalamnya sehingga bisa bergerak dan mempunyai motif dalam kehidupan di bumi. Unsur abiotik diantaranya adalah semua benda-benda di bumi seperti benda padat, air, mineral, udara, api, dan seterusnya dimana memiliki keterkaitan dengan hukum alam diataranya hukum fisika dan kimia. Benda-benda tersebut sekalipun dikatakan sebagai benda mati tapi mempunyai reaksi terhadap gaya tarik bumi (gravitasi), berat jenis, suhu udara, air, sinar matahari dan seterusnya. Seperti halnya tanah adalah unsur yang didalamnya ada makanan 
(mineral) yang dibutuhkan oleh tumbuhan, selanjutnya tumbuhan akan dimakan oleh hewan herbivora, hewan herbivora akan dimakan oleh hewan karnivora, selanjutnya karnivora bisa dikatakan sebagai hirarki mata rantai tertinggi akan mati dan tubuhnya akan terurai di tanah atau bumi kembali. Seterusnya siklus mata rantai makanan di bumi berputar. Terlihat semua unsur yang ada di bumi saling terkait dan membutuhkan untuk kelangsungan hidup termasuk manusia yang juga membutuhkan makan dan minum yang bersumber dari mata rantai makanan tersebut. Semua yang ada di bumi mulai dari unsur yang makro sampai mikro tertata dan teratur bekerja secara sinergi membentuk jaringan dan berinterakasi satu sama lain untuk menjaga keseimbangan alam.

Isu-isu yang terkait dengan lingkungan saat ini memang kurang menjadi prioritas daripada isu-isu pembangunan. Selama beberapa dekade terakhir, penelitian tentang perlindungan lingkungan di berbagai bidang dan sektor telah menjadi semakin penting karena meningkatnya perhatian pada pemanasan global, meningkatnya polusi, pencemaran limbah industri, dan masalah sampah, seperti penumpukan sampah baik di daratan dan juga di laut, serta sampah yang sulit terurai di alam dan juga masalah lingkungan lainnya. Para pakar lingkungan sedang mengkaji bagaimana perilaku manusia mempengaruhi lingkungan dan bagaimana cara mengelola dampak lingkungan dengan cara yang tepat. Untuk menyebarkan pesan lingkungan tersebut dibutuhkan upaya atau proses suatu mekanisme penyampaian pesan lingkungan yang sistematik.

Komunikasi lingkungan harus dilakukan mulai dari tingkat pemerintahan pusat sampai dengan di tingkat lokal, sehingga memiliki peran penting dalam menjembatani antara pemerintah melalui kebijakan dengan masyarakat. Masalah lingkungan dan kelangsungan yang berkelanjutan tidak mungkin hanya mengandalkan dari kesadaran masyrakat, sebagai contoh masalah sampah, sampah secara maknawi adalah 'buangan' atau sesuatu yang dibuang dan setelah itu secara memori manusia akan segera dilupakan. Manusia akan merasakan akibat (dampak) dari ulahnya setelah kebiasaan seperti buang sampah sembarangan atau membiarkan sampah menumpuk dan bau menyengat mulai dirasakan karena merugikan. Namun hingga sekarang masalah isu lingkungan masih sering mengabaikan pentingnya komunikasi lingkungan sebagai bagian vital dari tata kelola masalah lingkungan itu sendiri (Calder \& Beckie, 2011; Grodzinska-Jurczak \& Cent, 2011).

Salah satu upaya mengatasi masalah lingkungan adalah dengan adanya program atau gerakan Bank Sampah yang telah diatur dalam Undang-Undang Republik Indonesia Nomor 18 Tahun 2088 Tentang Pengelolaan Sampah dan Peraturan Pemerintah No 81 tahun 2012, Mengenai Pengelolaan Sampah Rumah Tangga Dan Sampah Sejenis Sampah Rumah Tangga. Dalam PP tersebut ditegaskan bahwa adanya kebijakan dan strategis nasional dalam pengelolaan sampah. Dalam bab III pasal 10 disebutkan penyelenggaraan pengelolaan sampah meliputi a) pengurangan sampah dan b) pengananan sampah. Sehingga ditetapkan bahwa setiap 
orang wajib melalukan pengurangan sampah dan pengananan sampah. Selanjutnya butir penanganan yang dimaksud seperti yang dijelaskan pada pasal 11 adalah: a) pembatasan timbunan sampah; b) pendauran ulang sampah; dan c) pemanfaatan kembali sampah. Penanganan sampah juga dijelaskan semua sampah yang berasal dari Kawasan pemukiman, Kawasan komersial, Kawasan industri, Kawasan khusus, fasilitas umum, fasilitas sosial dan fasilitas lainnya akan dilakukan dengan cara melalukan pemilahan, pengumpulan, pengangkutan, pengolahan dan akhirnya kepada pemrosesan akhir sampah. Sehingga untuk mewujudkan kebijakan ini setiap pengelola Kawasan pemukiman, Kawasan komersial, Kawasan industry, Kawasan khusus, semua fasilitas umum dan sosial wajib melalukan pengumpulan sampah dengan menyediakan: a) Tempat Pembuangan Sementara (TPS); b) TPS 3R (Reduce, Reuse, dan Recycle); c) alat pengumpul atau sampah terpilah. Selanjutnya, ada juga Peraturan Mentri Negara Lingkungan Hidup Republik Indonesia no 13 tahun 2012, tentang Pedoman Pelaksanaan Reduce, Reuse, dan Recycle melalui Bank Sampah.

Sebanyak 5.244 bank sampah yang tersebar di 34 provinsi atau 219 kabupaten/kota pada tahun 2017 meraup pendapatan sebesar Rp 1,48 miliar, naik 29 persen dibandingkan pendapatan tahun 2016 sebesar Rp 1,14 miliar, dan dari tahun 2015 sebesar Rp 1,01 miliar. Kasubsit sampah spesifik dan daur ulang, Direktorat pengelolaan sampah, Ditjen Pengelolaan Sampah, Limbah dan Bahan Beracun Berbahaya (PSLB3), Kementerian Lingkungan Hidup dan Kehutanan (KLH) Haruki Agustina mengatakan selain untuk mengurangi jumlah sampah, hal ini juga bisa menambah penghasilan bagi masyarakat. "Pendapatan dari pengelolaan sampah oleh 5.244 bank sampah yang tersebar di 34 propinsi atau di 219 kabupaten kota terus naik dari tahun ke tahun. Ini merupakan perkembangan baik dan menarik,". Dari 5.244 bank sampah berhasil mempekerjakan 163.128 orang, di mana 49 persen merupakan wanita yang sebagian besar merupakan ibu rumah tangga.

Selain itu, wanita merupakan aktor penting dalam keluarga dalam membantu pengelolaan sampah, mulai dari memisahkan sampah organik dan non organik, juga mendidik anak-anaknya dalam membuang dan memilih sampah organik dan non organik. "Dari sampah plastik, banyak ibu rumah tangga memanfaatkannya dan mendaur ulang menjadi berbagai macam kerajinan sehingga memiliki nilai ekonomis,". Untuk itu, para pengusaha dan pengusaha ritel diharapkan mau menyerap produk kerajinan dari daur ulang sampah, sementara masyarakat diharapkan dapat membeli agar industri kerajinan daur ulang sampah plastik makin terus maju dan berkembang. Menurut catatan $\mathrm{KLH}$, secara nasional mengelola sampahnya mencapai 65,2 juta ton pada tahun 2016, tahun 2017 mengelola 65,8 juta ton sampah. Kontribusi pengurangan sampah dari 5.244 bank sampah pada tahun 2015 hanya sebesar 0,01 persen, tahun 2016 naik 0,14 persen, dan tahun 2017 naik cukup signifikan 1,7 persen (merdeka.com, 27/02/2018). 
Salah satu Kota Madya yang menjalankan program Bank Sampah adalah Kota Tangerang Selatan yang sejak 2012 sudah mulai gerakan ini. Pemerintah Kota Tangerang Selatan mengeluarkan Perda No.3 Tahun 2013 tentang Pengelolaan Sampah untuk melaksanakan amanat dari UU 18 tahun 2088 yang menyebutkan harus ada perda pengolahan sampah. Perda yang dikeluarkan oleh Pemkot Tangerang Selatan tidak spesifik membahas mengenai Bank Sampah tapi pada Bab XIII mengenai Peran Masyarakat, pada pasal 42 yang berbunyi: 1) Masyarakat dapat berperan dalam pengelolaan sampah yang diselenggarakan oleh Pemerintah Daerah; 2) Peran sebagaimana dimaksu pada ayat (1) dapat dilakukan melalui: a) pemberian usul, pertimbangan, dan saran kepada Pemerintah Daerah; b) perumusan kebijakan pengelolaan sampah; c) pemberian saran dan pendapat dalam penyelesaian sengketa persampahan; d) menjaga kebersihan lingkungan; e) aktif dalam kegiatan pengurangan, pengumpulan, pemilahan, pengangkutan, dan pengolahan sampah. Selanjutnya peningkatan peran masyarakat dilaksanakan dengan cara: a) sosialisasi; b) mobilisasi; c) kegiatan gotong royong; d) pemberian intensif; e) mengembangan informasi peluang usaha di bidang persampahan; e) mengembangkan informasi peluang usaha di bidang persampahan; f) penyediaan media komunikasi; g) aktif dan secara cepat memberikan tanggapan; dan h) melakukan jarring pendapat aspirasi masyarakat. Tangerang Selatan sebagai wilayah perkotaan yang memiliki kontribusi besar terhadap volume sampah tertama sampah rumah tangga, dan industri. Kota Madya Tangerang Selatan juga memiliki permasalahan yang serius terkait dengan penumpungan sampah yang ada. Sampah menjadi salah satu permasalahan kota Tangerang Selatan (Tangsel).

Tangsel menghasilkan sampah kurang lebih 880 ton setiap hari. Dalam keterangan tertulis dari Dinas Lingkungan Hidup Pemkot Tangsel, Kepala Bidang Persampahan dari Dinas Lingkungan Hidup Pemkot Tangsel, Yepi Suherman, berfikir keras untuk menanggulangi sampah. Yepi mencetuskan dan perkenalkan program bank sampah kepada masyarakat. Gerakan ini yakni masyarakat memilah dan memanfaatkan sampah. Gerakan bank sampah di lingkungan kota Tangsel sejak 2013, sampai saat ini jumlah bank sampah yang sudah terbentuk dan sebanyak 202 bank sampah. Jumlah nasabah bank sampah se-Tangsel kurang lebih 4.000 orang (Detik.com, 19/5/2017). Wali Kota Airin mengaku permasalahan terbesar di Tangerang Selatan salah satunya adalah permasalahan sampah. Sehingga saat ini dia terus mengupayakan berbagai upaya untuk mengatasi persoalan sampah tersebut. Salah satunya juga bank sampah di lingkungan warga. Namun, sejak digerakkan tahun 2013 bank sampah yang aktif melapor sekitar 100 bank sampah atau hanya 50\% dari total keseluruhan. Partisipasi tinggi dari masyarakat menurut dia cukup signifikan dalam menjalankan bank sampah tersebut. Hal tersebut karena dalam menjalankan bank sampah itu sama sekali tidak ada anggaran dari pemkot, semua murni dari masyarakat. 
Tangerang Selatan sebagai wilayah perkotaan yang memiliki kontribusi besar terhadap volume sampah terutama sampah rumah tangga, dan industri. Kota Madya Tangerang Selatan juga memiliki permasalahan yang serius terkait dengan penumpungan sampah yang ada. Sampah menjadi salah satu permasalahan kota Tangerang Selatan (Tangsel). Tangsel menghasilkan sampah kurang lebih 880 ton setiap hari. Dalam keterangan tertulis dari Dinas Lingkungan Hidup Pemkot Tangsel, Kepala Bidang Persampahan dari Dinas Lingkungan Hidup Pemkot Tangsel, Yepi Suherman, berfikir keras untuk menanggulangi sampah. Yepi mencetuskan dan perkenalkan program bank sampah kepada masyarakat. Gerakan ini yakni masyarakat memilah dan memanfaatkan sampah. Gerakan bank sampah di lingkungan kota Tangsel sejak 2013, sampai saat ini jumlah bank sampah yang sudah terbentuk dan sebanyak 202 bank sampah. Jumlah nasabah bank sampah se-Tangsel kurang lebih 4.000 orang (Detik.com, 19/5/2017).

Wali Kota Airin mengaku permasalahan terbesar di Tangerang Selatan salah satunya adalah permasalahan sampah. Sehingga saat ini dia terus mengupayakan berbagai upaya untuk mengatasi persoalan sampah tersebut. Salah satunya juga bank sampah di lingkungan warga. Namun, sejak digerakkan tahun 2012 bank sampah yang aktif melapor sekitar 100 bank sampah atau hanya 50\% dari total keseluruhan. Partisipasi tinggi dari masyarakat menurut dia cukup signifikan dalam menjalankan bank sampah tersebut. Hal tersebut karena dalam menjalankan bank sampah itu sama sekali tidak ada anggaran dari pemkot, semua murni dari masyarakat.

Maka dalam rencana penelitian yang akan dilakukan penulis akan bertujuan diantaranya untuk mengetahui bagaimana esensi dari komunikasi lingkungan terkait bank sampah yang dilakukan oleh pemerintah kota Tangerang Selatan? Lalu bagaimana respon dan partisipasi masyarakat terkait gerakan bank sampah yang telah digalakkan? Selanjutnya penulis juga ingin mengetahui kenapa ada bank sampah yang bertahan dan maju sejak didirikan serta ingin mengetahui pula kenapa hampir separuh bank sampah yang telah berdiri tidak aktif? (komperasi). Terakhir penulis juga ingin mengetahui bagaimana bentuk pemberdayaaan masyarakat dengan gerakan bank sampah yang sudah berjalan.

Komunikasi adalah sebuah proses yang meliputi pengiriman dan penerimaan pesan serta pemahaman terhadap pesan yang disampaikan. Dalam komunikasi terdapat beberapa kegiatan yang dilakukan oleh pengirim pesan dan penerima pesan yaitu mendengarkan, berbicara, dan melakukan pengamatan. Jika kita telah memahami dengan baik apa dan bagaimana proses komunikasi berlangsung maka tahapan berikutnya adalah kita mulai dapat melakukan evaluasi terhadap komunikasi yang telah kita lakukan. Umumnya, evaluasi dilakukan terhadap berbagai unsur atau elemen atau komponen yang mendukung berlangsungnya proses komunikasi. Komponen-komponen komunikasi yang dimaksud adalah source, message, encoding, channel, decoding, receiver, feedback, context, noise, dan effect. 
Tabel: Komponen-Komponen Komunikasi Lingkungan dalam Perencanaan Sosial

\begin{tabular}{|c|c|c|}
\hline Source & Pengirim/ pembuat pesan. & $\begin{array}{l}\text { Pemerintah kota, tokoh } \\
\text { masyarakat, kelompok swadaya } \\
\text { masyarakat, swasta, akademisi, } \\
\text { LSM, masyarakat umum. }\end{array}$ \\
\hline encoding & $\begin{array}{l}\text { Pembentukan pesan } \\
\text { (symbol) }\end{array}$ & Bank Sampah \\
\hline Messege & $\begin{array}{l}\text { Informasi, symbol, verbal/ } \\
\text { nonverbal, sesuatu yang } \\
\text { disampaikan/ dikirim/ } \\
\text { ditujukan. }\end{array}$ & $\begin{array}{l}\text { Pesan Lingkungan: Sampah, } \\
\text { kerusakan, perbaikan, dan } \\
\text { kelestarian alam }\end{array}$ \\
\hline Channel & Saluran yang digunakan & $\begin{array}{l}\text { antarpribadi, kelompok, Organisasi, } \\
\text { media massa, media sosial. }\end{array}$ \\
\hline Decoding & $\begin{array}{l}\text { Menterjemahkan pesan } \\
\text { (interpretasi/ mengartikan, } \\
\text { memecahkan, membuka, } \\
\text { memaknai, memahami, etc. }\end{array}$ & $\begin{array}{l}\text { Komunikasi Lingkungan, } \\
\text { Pemberdayaan Masyarakat: } \\
\text { pengembangan sosial, politik, } \\
\text { lingkungan, personal/ spiritual, } \\
\text { ekonomi, dan budaya }\end{array}$ \\
\hline Receiver & Penerima pesan, & $\begin{array}{l}\text { Masyarakat (atas, menengah, } \\
\text { bawah), Swasta, akademik. }\end{array}$ \\
\hline Feedback & $\begin{array}{l}\text { Umpan balik, reaksi yang } \\
\text { dikembalikan }\end{array}$ & $\begin{array}{l}\text { Kepengurusan dan nasabah bank } \\
\text { sampah }\end{array}$ \\
\hline Context & Situasi, kondisi, lingkungan & Hanya $50 \%$ keatifan bank sampah \\
\hline noise & Ganguan, hambatan & Kendala SDM \\
\hline effect & $\begin{array}{l}\text { Dampak sikap/ tingkah laku } \\
\text { (kognitif, afektif, konatif/ } \\
\text { psikomotorik) }\end{array}$ & $\begin{array}{l}\text { Mengerti (sadar), merasakan, } \\
\text { bertindak atau mengabaikan, } \\
\text { menolak, tidak memahami, etc. }\end{array}$ \\
\hline
\end{tabular}

Setiap inovasi pasti tidak terlepas dari bagaimana pesan inovasi tersebut dikemas dan bagaimana cara menyampaikannya. Ada kaitan yang erat setelah identifikasi masalah dan pemetaan masalah sudah dilakukan dan perencanaan sosial sudah dirancang, lalu yang menjadi tantangannya adalah bagaimana rancangan perencanaan sosial yang sudah bertransformasi menjadi sebuah pesan agar sampai sesuai yang diinginkan dan efektif.

Komunikator inti dalam kasus bank sampah di Kota Tangerang Selatan adalah Pemerintah kota dan simbol esensialnya adalah ibu Airin Rachmi Diany sebagai iconic dari kota Tangerang Selatan, seperti kasus peneguran Mentri Susi terkait waduk Pamulang yang kotor sasaran tembaknya adalah langsung kepada pribadi walikota itu sendiri. Sebagai komunikator Pemerintah Kota Tangerang Selatan juga sebagai 'Perencana Sosial', maka yang harus dilakukan adalah penguatan kebijakan yang sudah 
legal tentang kebijakan pengolahan sampah industri dan rumahan dengan pengontrolan yang ketat. Pemerintah kota tidak bisa bekerja sendiri dan harus sinergi terutama dengan semua komunikator yang ada terkait pesan lingkungan "bank sampah", harus terus dikampanyekan dan mungkin dengan kemasan pesan yang kreatif dan lebih mengena kepada masyarakat.

Selanjutnya adalah saluran yang digunakan, dari informasi yang diamati penulis bahwa komunikasi kelompok yang lebih dominan, dan sudah dipastikan kelompok dan tokoh masyarakat akan menjadi jembatan yang efektif kepada masyarakat luas. Perencanaan kedepan justru adalah penguatan ke saluran lain yang lebih tepat sasaran. Misalnya generasi milenial adalah sasaran utama karena generasi muda adalah bibit dari perubahan suatu peradaban itu sendiri. Gerakan bank sampah adalah istilah yang sering digunakan oleh pemerintah kota, seperti Bapak Yepi Suherman yang selalu menggunakan istilah "gerakan" saat diwawancara media. Kata "gerakan" berarti masih dipergerakkan belum bergerak dengan sendirinya. Maka ini tantangan untuk menciptakan dan terus menjaga kelestraian budaya baru yang positif seperti memilah sampah organik dan anorganik. Terkait partisipasi masyarakat mengenai bank sampah memang masih didominasi oleh masyarakat menengah kebawah yang memang ada motif ekonomi yang kuat dibandingkan masyarakat kelas atas (yang berkecukupan), Pemerintah Kota sebagai komunikator sekaligus perencana sosial bisa membuat program yang dapat mensinergikan masyarakat yang beragam tersebut. Misalnya dengan melakukan kegiatan bazar yang di laksanakan di kompleks perumahan tapi ada agenda komunikasi lingkungan seperti membuka stand bank sampah, ada jualan yang pembayarannya dengan sampah ekonomis, dan upaya kreatif inovatif lainnya sehingga kondisi bisa dibuat sebagai upaya social engineering.

Decoding atau penerjemahan pesan dari bank sampah adalah sebuah bentuk pemberdayaan masyarakat yang sudah sangat terbukti dari partisipasi warga dan kelompok swadaya masyarakat yang ada, jumlahnya memang masih jauh sekitar 4.000 orang nasbah dibandingkan 1,4 juta penduduk kota Tangerang Selatan. Tapi yang 4.000 adalah orang-orang yang mempunyai jiwa sosial dan kepedulian kepada lingkungan. Memang belum diketahui sejauh mana motifnya menjadi nasabah, apakah sebatas ekonomi saja atau karena memahami permasalahan global yaitu masalah lingkungan. Ini bisa jadi salah satu yang akan dicari jawabannya pada penelitian selanjutnya. Mungkin masih kurang dari kalangan menengah dan atas pada umumnya. Tapi terkait dengan adanya bank sampah menyebabkan adanya rutinitas yang produktif dan membuat masyarakat berdaya.

Penerima pesan sudah pasti seluruh warga Tangerang selatan, yang jadi pertanyaan sepeti apa akses penyeberannya, tentunya cara masuk kelapisan masyarakat yang satu dengan yang lain pasti berbeda sesuai dengan kondisi dan situasi (kontekstual). Lalu umpan baik yang nyata adalah dengan adanya kerelaan menjadi pengurus bank sampah dan para nasabah yang begitu konsisten. Untuk ganguan (noise), dari pantauan awal penelitan ditemukan memang ada diantaranya masyarakat 
yang tidak suka melihat kekumuhan sampah terutama saat pengumpulan, tapi harus disadari semua kegiatan pasti berpotensi memiliki kendala dan hambatan. Sekarang bagaimana kesiapan kita menghadapinya daripada menghindarinya, karena tidak akan terselesaikan masalah apapaun kalau dengan cara menghidarinya. Efek atau dampak sudah pasti sangat dirasakan oleh pemerintah kota dan juga masyarakat terutama dampak yang positif karena memperjuangkan masalah sampah untuk puluhan atau ratusan tahun kedepan adalah bagaimana kita berpikir dan bersikap sekarang. Maka secara untuk ketidakaktifan sekitar $50 \%$ bank sampah yang sudah terbentuk harus melakukan telaah atau penelitian perencanaan sosial terbaru untuk menjawab persoalannya.

\section{Kesimpulan}

Bank sampah merupakan sebuah 'messege' yang menjadi bagian dari pesan komunikasi lingkungan. Untuk melaksanakan gerakan bank sampah tersebut maka perlu dilakukan sebuah perencanaan sosial. Inti dari perencanaan sosial adalah untuk melakukan preventif terhadap kemungkian dimasa depan yang tidak diharapkan. Gerakan bank sampah saat ini menjadi salah satu solusi efektif untuk menanggulangi masalah lingkungan terutama masalah sampah rumah tangga dan industri. Perencanaan sosial tidak seperti perencanaan lain seperti bidang esakta (ilmu alam), karena yang jadi objek nya adalah manusia, kelompok dan masyarakat. Semuanya mempunyai karakteristik yang khas baik secara individu maupun secara kolektif. Maka diperlukan strategi perencanaan yang efektif dan tepat guna. Keterkaitan perencanaan sosial dan komunikasi adalah seperti dua sisi mata uang, perencanaan sosial sangat membutuhkan proses komunikasi yang baik. Dengan memahami pemetaan komponen komunikasi perencana sosial dapat merancang langkah-langkah sesuai kondisi dan situasi sosial yang sedang berproses. Setelah membuka dan melihat komponen-komponen komunikasi, sebagai komunikator atau sebagai komunikan dapat melihat celah kekurangan atau kesalahan yang ditimbulkan oleh gangguan yang ada aliran proses komunikasi, seperti kenapa ada orang yang salah menterjemahkan pesan dari sumber pesan yang mengakibatkan sesuatu yang fatal seperti pertikaian bahkan sampai peperangan.

Dalam usaha memberdayakan (empowering) masyarakat banyak pilihan tindakan yang dapat dilakukan, baik oleh komunitas lokal, maupun oleh lembaga di luar komunitas, baik dari pemerintah maupun oleh swasta atau kelompok swadaya masyarakat. Bentuk tindakan sangat beragam, mulai dari bantuan dana, pembangunan sampai pada pendidikan. Namun demikian tidak semua bentuk tindakan ini sesuai dengan kondisi dan kebutuhan komunitas lokal. Untuk itu diperlukan perencanaan yang baik untuk memilih tindakan yang sesuai dan mungkin untuk diadaptasi dan dijalankan oleh komunitas. Dengan perencanaan sosial diharapkan akan diperoleh strategi 
pemberdayaan yang dapat diterima. Dengan kata lain adalah bahwa dalam sebuah perencanaan, sebuah keputusan tindakan jangka pendek harus dapat mendukung sasaran jangka panjang yang strategis. Untuk itu sebuah perencanaan harus dievaluasi dan dinegosiasikan secara komprehensif sehingga anggota komunitas yang akan diberdayakan dapat dan sanggup menerima solusi yang nampaknya sulit dan mahal ketika dilakukan dalam jangka pendek.

\section{Daftar Pustaka}

Azwar, Azrul. (1990). Pengantar Ilmu Lingkungan. Jakarta: Mutiara Sumber Widya

Cox, Robert. (2010). Environmental communication and the public sphere. 2ndedition. London: Sage publications.

Grodzinska-Jurczak M., Cent, J. (2011). Expansion of Nature Conservation Areas: Problems with Natura 2080 Implementation in Poland. Environment Management, Volume 47, pp. 11-27.

Kodoatie, Robert J. (2083). Manajemen dan Rekayasa Infrastruktur. Yogyakarta: Pustaka Pelajar.

Littlejohn, Stephen W. \& Karen A. Foss. (2089). Encyclopedia of communication theory. London: SAGE publications.

Sejati, Kuncoro. (2089). Pengolahan Sampah Terpadu, Yogyakarta: Kanisius.

\section{Internet}

Tempo.co, 23 Agustus 2015, Airin Tak Berdaya Hadapi Masalah Sampah Tangerang Selatan, https://metro.tempo.co/read/694231/airin-tak-berdaya-hadapi-masalahsampah-tangerang-selatan, diakses 15 Mei 2018. 
Tempo.co, 30 Maret 2016, Tangsel Targetkan Bentuk 700 Bank Sampah Hingga Akhir Tahun,https://bisnis.tempo.co/read/758353/tangsel-targetkan-bentuk-700bank-sampah-hingga-akhir-tahun, diakses 15 Mei 2018.

Tangseloke.com, 10 September 2013, Bank Sampah Tangsel Diberikan Modal Bantuan, https://tangseloke.com/2013/09/10/bank-sampah-tangsel-diberikan-modalbantuan/, diakses 15 Mei 2018.

Arthagraha.com, 13 October 2016, Pemkot Tangerang Selatan bekerjasama dengan Bank Artha Graha Internasional dan Yayasan Bunga Melati Indonesia, dalam rangka motivasi \& evaluasi Bank Sampah Melati Bersih Tangsel Tahun 2016, http://www.arthagraha.com/main/readnews/pemkot-tangerang-selatanbekerjasama-dengan-bank-artha-graha-internasional-dan-yayasan-bunga-melatiindonesia-dalam-rangka-motivasi-evaluasi-bank-sampah-melati-bersih-tangseltahun-2016, diakses 15 Mei 2018.

Tangselbanget.com, 19 Mei 2017, Sampah Tangsel 880 Ton Setiap Hari, Apa Yang Dilakukan Pemkot, http://tangselbanget.com/berita/sampah-tangsel-880-tonsetiap-hari.html, diaskes 15 Mei 2018.

Agualestari.aqua.com, 3 Maret 2017, RBU Tangerang Selatan Bantu Hidupkan Kembali Bank Sampah Mekarsari, http://aqualestari.aqua.com/article/single/rbutangerang-selatan-bantu-hidupkan-kembali-bank-sampah-mekarsari/, diakses 15 Mei 2018.

Bidiktangsel.com, 23 Januari 2018, DLH Tangsel Apresiasi Bank Sampah Tegal Rotan, http://bidiktangsel.com/berita-tangsel/2018/dlh-tangsel-apresiasi-bank-sampahtegal-rotan.html, diakses 15 Mei 2018.

Metro.sindonews.com, 1 Juni 2017, Miliki 208 Bank Sampah, Tangsel Bertekad Kendalikan Sampah, https://metro.sindonews.com/read/1210038/171/miliki-208-banksampah-tangsel-bertekad-kendalikan-sampah-1496344503, diakses 15 Mei 2018.

Tribunnews.com, 21 Agustus 2017, Kota Tangerang Selatan Miskin Bank Sampah, http://www.tribunnews.com/metropolitan/2017/08/21/kota-tangerang-selatanmiskin-bank-sampah, diakses 15 Mei 2018.

Kabartangsel.com, 10 Juli 2015, Tanam Sayuran di Lahan Perkotaan, Bank Sampah Melati Bersih Jadi Tempat Percontohan, https://kabartangsel.com/berhasil-tanam- 
sayuran-di-lahan-perkotaan-bank-sampah-melati-bersih-jadi-tempatpercontohan/, diakses 15 Mei 2018.

Kabartangsel.com, 6 Juni 2014, Walikota Tangsel: Kami Menargetkan Setiap RW Mempunyai Bank Sampah, https://kabartangsel.com/walikota-tangsel-kamimenargetkan-setiap-rw-mempunyai-bank-sampah/, diakses 15 Mei 2018.

kabartangsel.com, 23 Juli 2013, Airaditas, Bank Sampah Kota Tangsel, https://kabartangsel.com/airaditas-bank-sampah-kota-tangsel/, diakses $15 \mathrm{Mei}$ 2018.

Radartangsel.com, 25 Agustus 2017, Maksimalkan Bank Sampah, Tangsel Targetkan Adipura,http://www.radartangsel.com/tangsel/pamulang/2017/08/25/maksimal kan-bank-sampah-tangsel-targetkan-adipura, diakses 2018.

PalapaNews.com, 19 Desember 2017, Warga Tangsel Didorong Bentuk Bank Sampah, https://palapanews.com/2017/12/19/warga-tangsel-didorong-bentuk-banksampah/, diakses 15 Mei 2018.

Detik.com,19 Mei 2017, Jurus Pemkot Tangsel Tangani Sampah yang Menumpuk, https://news.detik.com/berita/d-3505753/jurus-pemkot-tangsel-tanganisampah-yang-menumpuk, diakses 15 Mei 2018. 


\section{Lampiran:}

\section{Kegiatan Penimbangan Sampah di BSMB Anggrek}

Late Post: 10 Mei 2018

Bank Sampah Melati Bersih

Jl. Anggrek, Pamulang Barat, Pamulang, Tangerang Selatan

Kegiatan Penimbangan Sampah
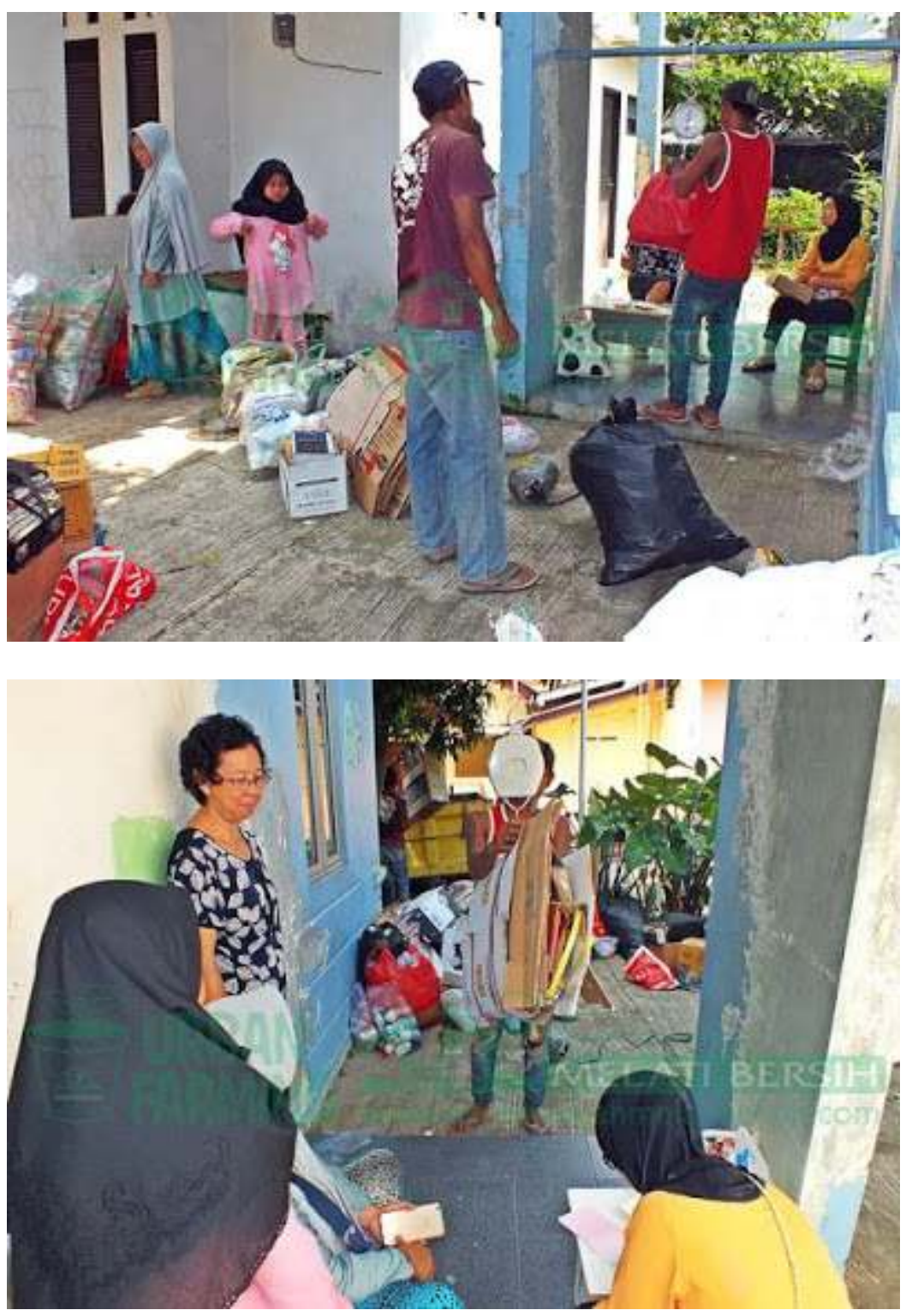

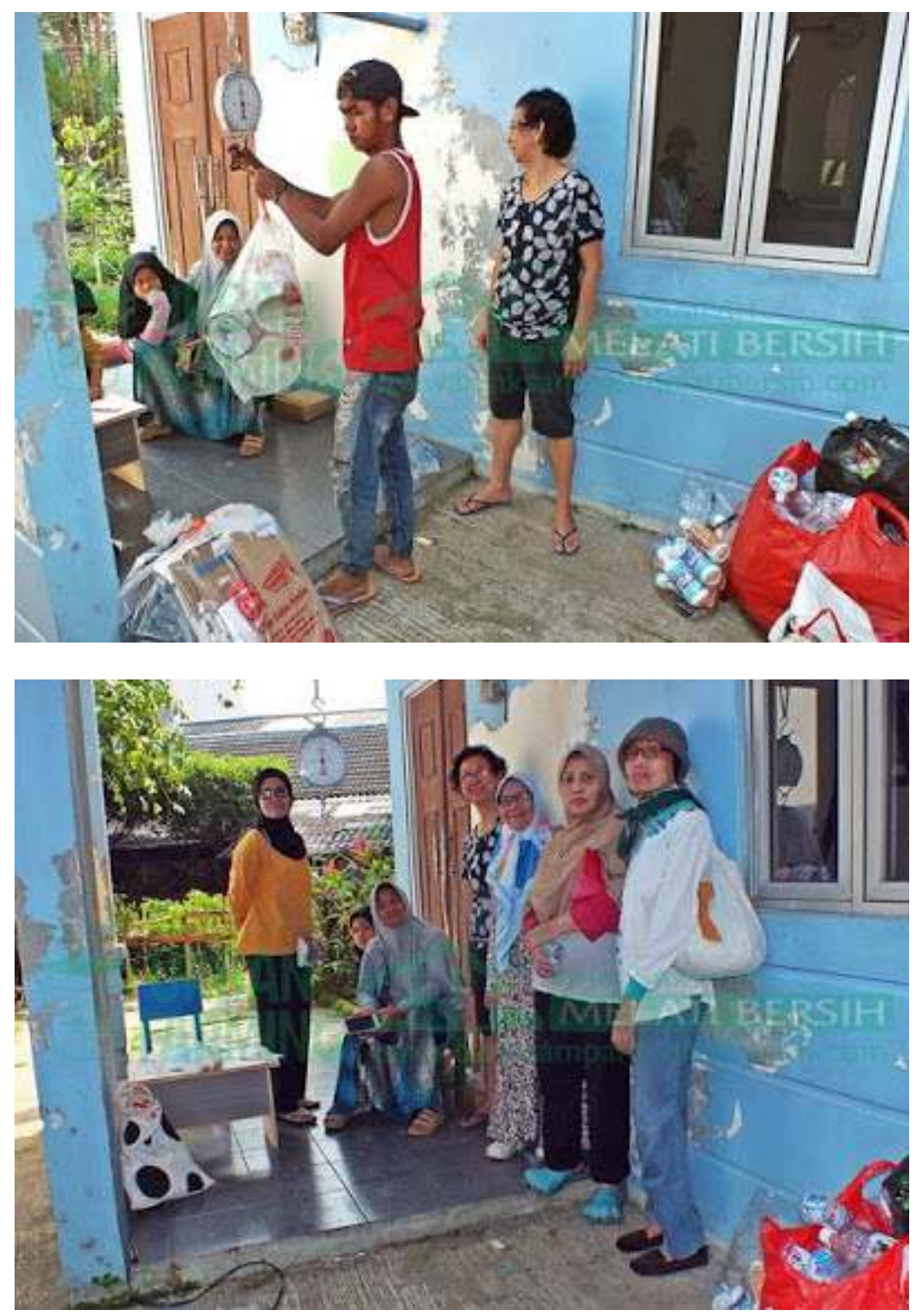

Sumber: http://www.banksampahmelatibersih.com/ 